\title{
Assessments of moisture fluxes east of the Andes in South America in a global warming scenario
}

\author{
Wagner Rodrigues Soares* and Jose Antonio Marengo \\ Center for Weather Forecasts and Climate Studies (CPTEC/INPE) São Paulo, Brazil
}

\begin{abstract}
The HadRM3P regional model from the UK Hadley Centre has been used to assess the moisture flux and the low-level jet (LLJ) east of the Andes in South America over two time periods: the first can be understood as the current climate and covers the period from 1980 to 1989; the second covers the period from 2080 to 2089 under a future global warming climate as projected by the Intergovernmental Panel on Climate Change (IPCC) Special Report on Emissions Scenarios (SRES) A2 high-emission scenario. The results are analyzed considering the vertically integrated moisture transport in the lower atmosphere and the moisture flux between the two core areas of South America - the Amazon Basin and the La Plata River Basin. In order to analyze the moisture transport east of the Andes, composites of South American LLJs were built based on the wind speed and vertical wind shear following the modified Bonner criteria 1 used to define LLJs. Integrations along the lateral boundaries of the two basins show that there could be a more intense moisture transport from tropical regions available to feed the mesoscale convective systems in the subtropical La Plata Basin in the IPCC A2 scenario, as compared to the present. This is because of the intense flow to the south associated with a faster LLJ bringing more moisture from the Amazon Basin southwards. It was also observed that the presence of the LLJ affects moisture convergence in the Amazon Basin in the current climate as well as in the warmer climate. In the future high-emission scenario A2, a more intense LLJ in a global warming climate suggests increased moisture transport from north to south east of the Andes as compared to the present. Copyright (C) 2008 Royal Meteorological Society
\end{abstract}

KEY WORDS low-level jet; climate change; moisture flux

Received 15 October 2007; Revised 1 October 2008; Accepted 4 October 2008

\section{Introduction}

In several regions of the globe, strong meridional fluxes are observed in the lower atmosphere along the mountain ranges. Such events have a maximum wind speed in the lower levels of the atmosphere (below $2000 \mathrm{~m}$ ) and are known as low-level jets LLJ (Paegle, 1998). LLJ events occur on the east side of elevated topography and are associated with large-scale circulations extending over large areas, such as the Rocky Mountains in the USA (Bonner, 1968; Whiteman et al., 1997; Douglas et al., 1998) and the Andes in South America (Douglas et al., 1998; Berbery and Collini, 2000; Paegle et al., 1998; Marengo et al., 2004; Vera et al., 2006a; Saulo et al., 2007 among others). Jets are also observed westward of topography, but these may not be important in the transport of moisture.

The studies by Bonner and Paegle (1970) as well as Paegle (1998) and Marengo et al. (2004) suggest similarities between the Rocky Mountains and the Andes Cordillera and their effects on the occurrence of the jet. These mountains extend from the tropical regions to high latitudes, blocking the zonal circulation in lower

\footnotetext{
* Correspondence to: Wagner Rodrigues Soares, Center for Weather Forecast and Climate Studies, Rod. Presidente Dutra, Km 40, 12630000 Cachoeira Paulista/SP, Brazil. E-mail: wsoares@cptec.inpe.br
}

levels and leading to the channelling of the wind. For instance, the moisture from the Gulf of Mexico in North America and northern tropical Atlantic Amazon in South America is transported by the LLJ to the central regions of their continents, i.e. to the Mississippi and Amazon river basins, respectively (Berbery and Collini, 2000).

In South America, the LLJ is known as the South American low-level jet (SALLJ) (Saulo et al., 2000; Marengo et al., 2004). The SALLJ is a component of the South American monsoon system and transports moisture from the Amazon Basin to the La Plata Basin, affecting the weather and the climate east of the Andes and at the exit point of the jet in the southern Brazil-northern Argentina region (Marengo et al., 2004; Vera et al., 2006a,c). Thus, occurrences of the SALLJ can, through the intense moisture flow and associated strong convective clouds in the exit region of the jet, generate rainfall extremes that produce floods (Paegle, 1998; Liebmann et al., 2004; Marengo et al., 2004).

The circulation patterns of the SALLJ can be summarized as follows: moisture is brought from the tropical Atlantic into the Amazon Basin by the trade winds. Once they flow over Amazonia, the air masses can gain more moisture through the intense evapotranspiration of the forest (Salati, 1987; Marengo, 2005). After that, the trade winds experience a shift in direction due to the 
topographic blocking by the Andes and then flow parallel to the Andes towards south/southeast South America (southern Brazil and northern Argentina). Marengo et al. (2004) show that this transport exhibits an annual cycle, where in summer, the moisture that goes into the La Plata Basin is mostly from the Amazon region. In winter, on the other hand, even though we can have moisture transport from the Amazon region, it is observed that the moisture transport of the oceanic origin associated with the annual cycle of the South Atlantic subtropical high (SASH) is stronger and dominates the annual cycle of the SALLJ.

The Amazon region contains the largest rainforest on the planet, with an area of about 7 million $\mathrm{km}^{2}$. This basin and the tropical forest ecosystem play an important role in the global energy, water and carbon balances. The La Plata Basin represents a region of great economic importance in South America. It includes the southern Brazilian states of Paraná, Santa Catarina and Rio Grande do Sul, plus Uruguay and northern Argentina. Economic activities developed in this basin, including agriculture and the generation of hydroelectric power, are sensitive to the variability of the weather and climate, becoming vulnerable to impacts related to the strong moisture transport by the jet and subsequent intense rainfall events.

Several studies based on a few isolated upper-air observations (Douglas et al., 1998; Misra et al., 2000; Marengo and Soares, 2002; Marengo et al., 2004; Nicolini and Saulo, 2006 and Liebmann et al., 2004) or modelling (Berri and Inzunza, 1993; Nogues-Paegle and Mo, 1997; Paegle, 1998; Saulo et al., 2000; Herdies et al., 2002; Vernekar et al., 2003) have documented the SALLJ and the moisture transport over South America in the current climate. However, there are not many studies about the impact of global warming and climate change on the variability and characteristics of the SALLJ, and on the concentration of moisture in the lower atmosphere.

Since 1988, the Intergovernmental Panel on Climate Change (IPCC) has been assessing the climate change under different scenarios of greenhouse gas emissions and analyzing also the scientific basis of the climate change, its impact, vulnerability and mitigation. The IPCC considers the scientific basis for climate projections into the future, and documents and quantifies its results, taking uncertainties into account. The issue of changes in the intensity of the South American monsoon system under global warming scenarios is something relatively new and is being considered in this study. The main question is this: what would be the impact of global warming upon the moisture transport from the Amazon to the La Plata Basin and how would the SALLJ behave in the future?

Analysis of the models from the Coupled Model Intercomparison Project (CMIP3) that contributed to the assessment of future climate change scenarios in South America in the IPCC AR4 (Li et al., 2006; Vera et al., 2006b; Christensen et al., 2007; Meehl et al., 2007 and references quoted therein) has produced climate projections for the future, using the IPCC AR4 global models
(Li et al., 2006; Vera et al., 2006b; Meehl et al., 2007 and the references quoted). The models used to evaluate future climate changes have, therefore, evolved over time. Global models have allowed for a better scientific understanding of anthropogenic global climate change and this has led to the developments of commensurate mitigation strategies. However, at the regional scale, there remains an urgent need for relevant, targeted projections of regional climate change. Climate projections have been derived from the regional models for South America (Marengo and Ambrizzi, 2006; Alves 2007; Ambrizzi et al., 2007; Marengo et al., 2008). Such studies analyze changes in the temperature and rainfall as well as extreme climate events for the end of the 21st century from the scenarios of low and high emissions of greenhouse gases $\mathrm{A} 2$ and $\mathrm{B} 2$ of IPCC, respectively.

However, these studies do not analyze the behaviour of the meridional moisture transport on the east side of the Andes in South America, associated with possible changes in the SALLJ activity. Marengo et al. (2007), using dynamic downscaling, showed an increase in the frequency of extreme events of rain in the far western end of the Amazon and in the south of Brazil. It is possible that this is a consequence of a future change in the regime of the transients, probably associated with cold fronts from the south or more frequent and/or intense SALLJs in a warmer climate.

The use of the dynamic downscaling technique in the generation of scenarios of the future climate makes for a better understanding of the variability typical of phenomena such as the SALLJ. Its high resolution can better present the mechanisms of surface and local factors (vegetation and topography) that affect the regional climate. Dynamic downscaling can contribute by providing details of the simulated patterns that are not obvious from global models and this favours the investigation of moisture transport patterns in the low levels of the atmosphere, when considering projections for possible future climate under global warming.

In this article we focus on quantification, for the present and future climate, of the moisture flux and horizontal moisture convergence over two regions, the Amazon and La Plata basins on seasonal and annual levels, focusing on the average behaviour during the present climate and at the climate at the end of the 21 st century. To this end, we use two long-term simulations of 10 years each. The first covers the period from 1980 to 1989 ('present climate'); the second covers the period from 2080 to 2089 ('future climate'). The future climate is for the IPCC SRES (Special Report on Emissions Scenarios, Nakicenovic et al., 2000) A2 (high emission), using the HadRM3P regional model, which was run in the Providing Regional Climates for Impacts Studies (PRECIS) system(Jones et al., 2004).

The analyses presented have generated an opportunity to check the behaviour of the PRECIS system in simulating SALLJ events and moisture transport associated with the jet in warmer future climates. 


\section{Data and methods}

\subsection{Characteristics of the regional model}

PRECIS is a regional climate modelling system developed by the UK Hadley Centre allowing the regional model HadRM3P to be run over any area of the globe (see Jones et al., 2004, which also includes a detailed description of HadRM3P). There are 19 vertical levels and 2 horizontal resolutions to pick from HadRM3P. In this study, a 50-km horizontal resolution and 1-day temporal resolution were used. Lateral boundary conditions for HadRM3P are available from a range of modeland observation-based sources. In this study, they are obtained from the global atmospheric model, HadAM3P. The horizontal resolution of HadAM3P is $1.25^{\circ}$ latitude by $1.875^{\circ}$ longitude and the model formulation is the same as HadRM3P.

As suggested in the PRECIS technical manual, the simulations were initiated in December of 1979 and December of 2079 and run until the end of 1989 and 2089, respectively. The extra integration time was assumed to be sufficient to allow for model 'spin-up', which should be a few days for the atmosphere, although for soil processes (moisture) it could take a few seasons (Giorgi and Mearns, 1999) or even a few years (Robock et al., 1998).

Rowell (2005) described and synthesized the experimental design of the driving HadAM3P experiment as follows. The HadAM3P 1980-89 simulation is forced by observed sea-surface temperatures (SSTs) and sea-ice from the HadISST1 dataset (Rayner et al., 2003). For the future period, 2080-89, HadAM3P is forced by SSTs which are obtained from observed SSTs altered by the sum of mean changes and trends calculated from a global coupled model projection. The coupled integration was performed with HadCM3 (Gordon et al., 2000) whose atmospheric component, HadAM3 (Pope et al., 2000), is the basis for HadAM3P (Jones et al., 2005). The same SSTs were used as the lower boundary condition for the HadRM3P simulations.

The domain utilized (shaded grey in Figure 1) appears to be sufficiently large so that the regional model can develop its own internal circulation on a regional scale, but not so large that the climate of the HadRM3P would depart significantly from the global model in the centre of the domain (Giorgi and Mearns, 1999; Chou et al., 2005).

\subsection{Simulations using HadRM $3 \mathrm{P}$ and characteristics} of the IPCC warming scenario

For this study, two long-term simulations were performed using HadRM3P with a spatial resolution of $50 \mathrm{~km}$ (latitude/longitude) and a time step of 1 day from which the climate projections were obtained for the two 10year periods. The first simulation covers the period from 1980 to 1989 and can be considered as current climate. The second simulation embraces the period from 2080 to 89 and represents a possible future climate from the IPCC SRES A2 scenario. The CO2 concentration in the

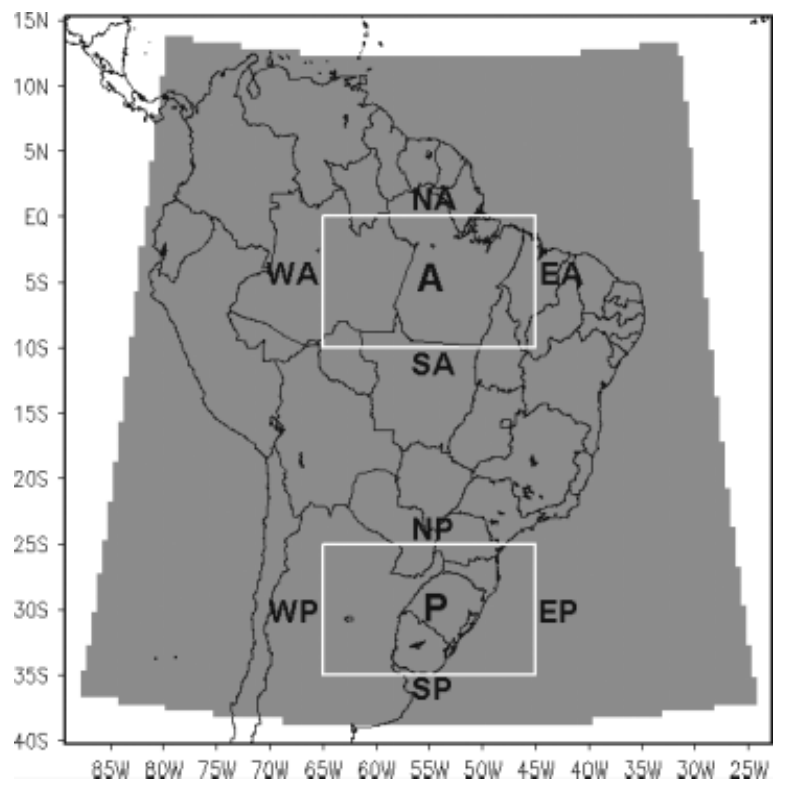

Figure 1. Areas under study shown in the regional model. The rectangles mark the regions of the Amazon (A) and La Plata basins (P).

SRES A2 is about $\sim 300 \mathrm{ppm}$ during the 1980 s and about $\sim 700 \mathrm{ppm}$ during 2080s. The $\mathrm{NO}_{2}$ concentrations are about 280 and $400 \mathrm{ppb}$ and the $\mathrm{CH} 4$ concentrations are from 1500 and $3200 \mathrm{ppb}$ during the decades of 1980 and 2080, respectively (IPCC, 2007a,b).

We were only able to make one model run in this study due to limited computational resources.

For the proposed assessments of moisture transport and moisture convergence at lower levels, mean flow and SALLJ composites for present climate have been prepared for the 1980-89 present-climate simulations from the HadRM3P. Evaluations of the simulated present climate are done using the National Centers for Environmental Prediction-National Center for Atmospheric Research (NCEP-NCAR) reanalyses (Kalnay et al., 1996). For rainfall observations we use the Climate Research Unit (CRU) gridded data set (New et al., 2001). Simulated present precipitation was compared with CRU. The grid size of the HadRM3P model was interpolated to the $2.5^{\circ}$ latitude-longitude grid of the NCEP-NCAR reanalyses.

Comparing present precipitation from the model with the CRU data, Alves (2007) shows that the regional model is too dry over the Amazon region while in the La Plata basin region, the model is too wet. This bias could be related to the fact that the CRU data set includes fewer reporting stations in regions such as Amazonia and Central Brazil (New et al., 2001). According to Alves (2007), besides these biases, the seasonal cycle of precipitation and temperature and the timing of the peak season, as well as the main large-scale circulation patterns, are well reproduced in South America.

\subsection{Detection of low-level jet events}

To detect and characterize SALLJ events, the modified Bonner criteria 1 (Bonner, 1968) were used. These 
modified criteria specify that the magnitude of the wind has to be equal to or larger than $12 \mathrm{~m} \mathrm{~s}^{-1}$ on the $850 \mathrm{hPa}$ level, the vertical wind shear has to be at least $6 \mathrm{~m} \mathrm{~s}^{-1}$ between the 850 and $700 \mathrm{hPa}$ levels and the meridional component of the wind has to be negative and larger in magnitude than the zonal component. These modified criteria were applied for the daily data at a grid point in Santa Cruz de la Sierra $\left(16.7^{\circ} \mathrm{S}, 63^{\circ} \mathrm{W}\right)$ in Bolivia, a location that represents the main axis of the jet, as in previous studies (Douglas et al., 1998; Saulo et al., 2000; Nicolini et al., 2002; Salio et al., 2002; Marengo et al., 2004 and Saulo et al., 2007 among others). Later on, composites of SALLJ episodes were assembled by grouping SALLJ events in each season of the year, for the future and present climate.

\subsection{Definition of the area of study}

The La Plata Basin is influenced by the annual cycle of moisture in the lower levels of the atmosphere, mainly from the tropical region of South America. The Amazon forest is one of the sources of moisture for regions in the south of Brazil such as the La Plata Basin region (SALLJ exit region), particularly during spring and summer. Other moisture sources for this region are: moisture associated with the presence of the SASH and the sea breeze, mainly during fall and winter.

With the objective of quantifying the moisture flux between the Amazon and the La Plata basins, two areas were chosen whose lateral borders are shown in Figure 1.

The two areas chosen for the computation of horizontal moisture divergence were A (Amazon Basin) latitude $=10^{\circ} \mathrm{S}, 0^{\circ}$; longitude $=65^{\circ} \mathrm{W}, 45^{\circ} \mathrm{W}$ and $\mathrm{P}(\mathrm{La}$ Plata Basin) latitude $=25^{\circ} \mathrm{S}, 35^{\circ} \mathrm{S}$; longitude $=65^{\circ} \mathrm{W}$, $45^{\circ} \mathrm{W}$. The lateral borders of those areas were established as: north of the Amazon Basin (NA), latitude = $0^{\circ}$; longitude $=65^{\circ} \mathrm{W}, 45^{\circ} \mathrm{W}$, south of the Amazon basin (SA), latitude $=10^{\circ} \mathrm{S}$; longitude $=65^{\circ} \mathrm{W}, 45^{\circ} \mathrm{W}$, east of the Amazon Basin (EA), longitude $=45^{\circ} \mathrm{W}$; latitude $=0^{\circ}, 10^{\circ} \mathrm{S}$, west of the Amazon Basin (WA), longitude $=65^{\circ} \mathrm{W}$; latitude $=0^{\circ}, 10^{\circ} \mathrm{S}$, north of the La Plata basin (NP), latitude $=25^{\circ} \mathrm{S}$; longitude $=65^{\circ} \mathrm{W}$, $45^{\circ} \mathrm{W}$, south of the La Plata Basin (SP), latitude $=35^{\circ} \mathrm{S}$; longitude $=65^{\circ} \mathrm{W}, 45^{\circ} \mathrm{W}$, east of the La Plata Basin (EP), longitude $=45^{\circ} \mathrm{W}$; latitude $=25^{\circ} \mathrm{S}, 35^{\circ} \mathrm{S}$, west of the La Plata Basin (WP), longitude $=65^{\circ} \mathrm{W}$; latitude $=$ $25^{\circ} \mathrm{S}, 35^{\circ} \mathrm{S}$.

2.5. Quantification of the moisture flux and horizontal moisture divergence

The vertically integrated moisture flux was calculated from the following equations:

$$
\begin{aligned}
& Q_{v}=\frac{1}{g} \int_{p t}^{p o} q v d p \\
& Q_{u}=\frac{1}{g} \int_{p t}^{p o} q u d p
\end{aligned}
$$

Where $Q_{v}$ is the meridional moisture flux, $Q_{u}$ is the zonal moisture flux, $g$ is gravity, $q$ is the specific humidity, $u$ and $v$ are the zonal and meridional components of the wind, and $p t$ and $p o$ represent the pressure at $700 \mathrm{hPa}$ and the surface, respectively (Rao et al., 1999). Marengo et al., 2004 show that the impact of the SALLJ on moisture transport on the east side of the Andes is more strongly felt below the $700 \mathrm{hPa}$ level, where most of the moisture is concentrated.

The moisture flux along the lateral borders was calculated from the following equations:

$$
\begin{aligned}
Q_{j} & =\int_{l a 1}^{l a o} Q_{i} d y \\
Q_{k} & =\int_{l o 1}^{l o o} Q_{i} d x
\end{aligned}
$$

In Equations (3) and (4), the integration is made by fixing the latitude or longitude along the borders. The index $j$ defines the longitude of the eastern or western borders (integration towards y), $l_{a 1}$ is the latitude of the southern border and $l_{a 0}$ is the latitude of the northern border. The index $i$ defines the meridional or zonal moisture flux already vertically integrated. The index $k$ (integration towards $\mathrm{x}$ ) defines the latitude to define the northern or southern borders. $l_{o 1}$ is the longitude of the western border and $l_{o 0}$ is the longitude of the eastern border.

The horizontal moisture divergence was obtained from $Q_{v}$ and $Q_{u}$, which provided the vertically integrated zonal and meridional moisture fluxes. The calculation was made at each grid point using finite differences. The results are shown for four seasons: December-JanuaryFebruary (DJF), March-April-May (MAM), June-JulyAugust (JJA) and September-October-November (SON). In the results, negative values of divergence mean convergence.

\section{Results and discussion}

3.1. Evaluation of the regional model in the low levels of the atmosphere for the current climate

The moisture flux as well as the horizontal moisture divergence fields were derived from the specific humidity and components of the wind from the surface to $700 \mathrm{hPa}$ and surface pressure. For evaluation purposes, the specific humidity and zonal and meridional components of the wind and surface pressure generated from the regional model HadRM3P were compared to those derived from the NCEP-NCAR reanalyses.

In this section, the grid size of the HadRM3P model was interpolated to the $2.5^{\circ}$ latitude-longitude grid of the NCEP-NCAR reanalyses.

Figure 2 shows the vertical mean water vapour fields. Figure 2(a) represents the NCEP reanalysis seasonal (DJF) mean field for the period from 1980 to 1989 and Figure 2(b) represents the same field and period from the HadRM3P simulations. The two figures show 
(a)

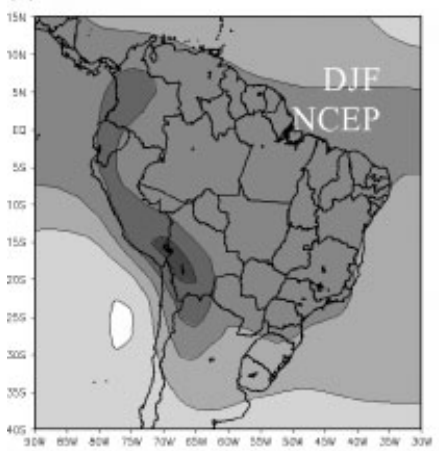

(d)

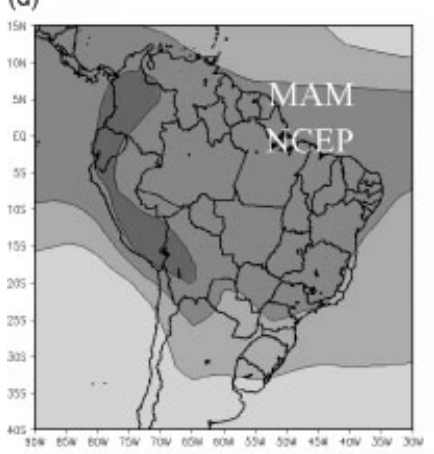

(g)

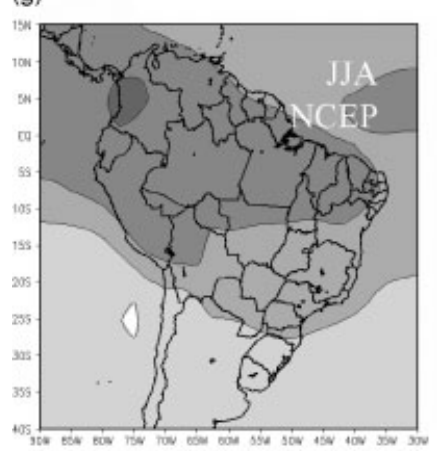

(j)

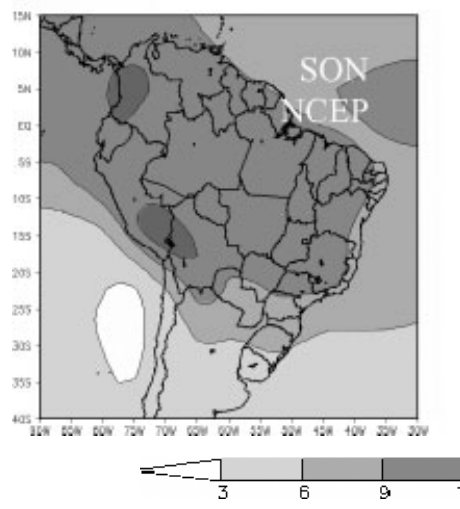

(b)

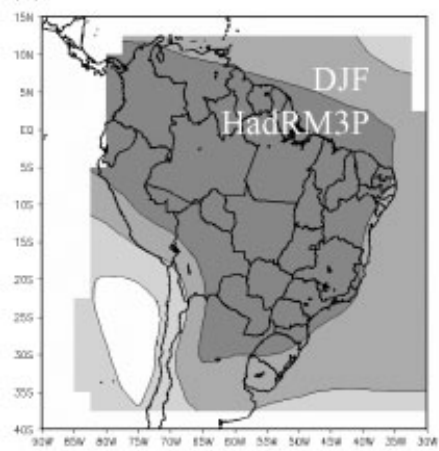

(e)

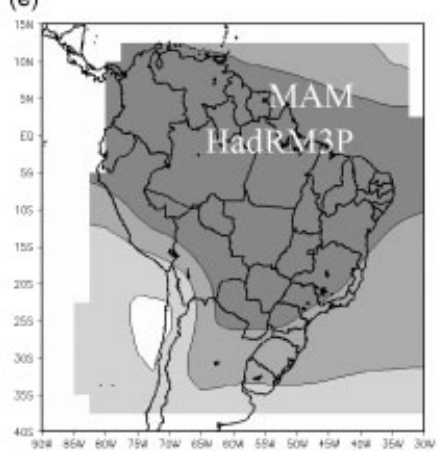

(h)

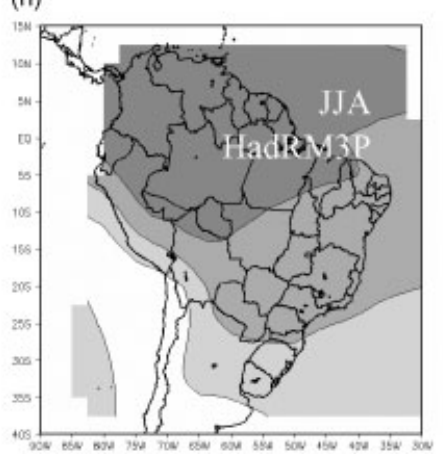

(k)

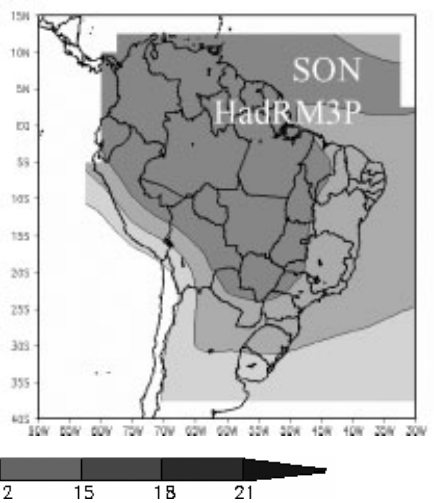

(c)

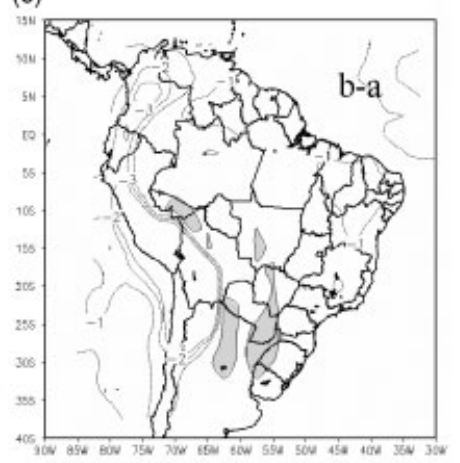

(f)

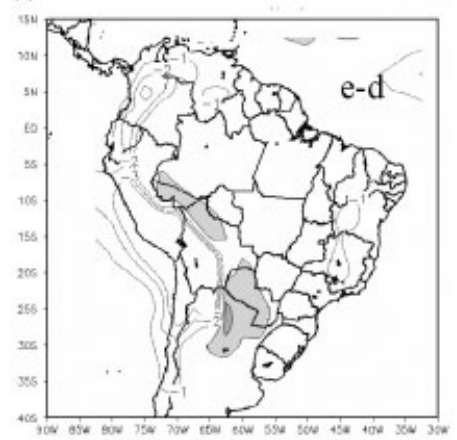

(i)

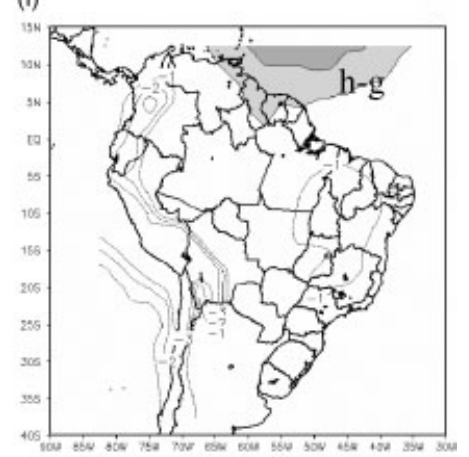

(I)

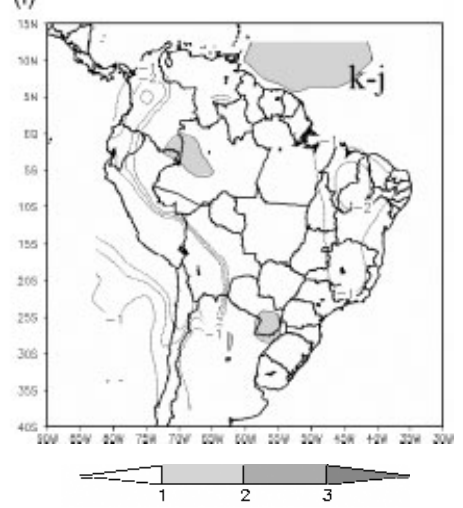

Figure 2. Specific humidity (g.kg ${ }^{-1}$ ) between the surface and $700 \mathrm{hPa}$. Figures (a) (DJF), (d) (MAM), (g) (JJA) and (j) (SON) were obtained from NCEP reanalyses for the period 1980-1989. Figures (b) (DJF), (e) (MAM), (h) (JJA) and (k) (SON) were obtained from HadRM3P for same period. The Figures (c), (f), (i) (e) and (l) are the difference fields between (b) and (a), (e) and (d), (g) and (h), (e) (k) and (j) respectively. Units are $\mathrm{g} \mathrm{kg}^{-1}$.

a pattern of similarities in the spatial distribution and the values. Specific humidity varies from 3 to $9 \mathrm{~g} \mathrm{~kg}^{-1}$ in both NCEP-NCAR and HadRM3P reanalyses over South America, except in an area close to the Andes, where the reanalyses show higher values.
Figure 2(c) shows the difference between the reanalysis and model fields. Figure 2(c) shows a difference over the continent of less than $1 \mathrm{~g} \mathrm{~kg}^{-1}$, while over the Andes this difference reaches $3 \mathrm{~g} \mathrm{~kg}^{-1}$. Over other regions of South America, the regional models underestimate 
specific humidity relative to the NCEP reanalyses by about $1 \mathrm{~g} \mathrm{~kg}^{-1}$ in various seasons of the year. The regional model projections have larger moisture values (by about $2 \mathrm{~g} \mathrm{~kg}^{-1}$ ) than the NCEP-NCAR reanalyses over northern Argentina and Paraguay, while over a region between 10 and $24^{\circ} \mathrm{S}$ and $45^{\circ} \mathrm{W}$ (Figure 2(f)), the model values are lower than those in the reanalyses. In the region between $10^{\circ} \mathrm{N}$ and $2^{\circ} \mathrm{N}$ during austral winter (JJA), which corresponds to the rainy season in the northern South America the regional model presents large specific humidity values about $\sim 1-2 \mathrm{~g} \mathrm{~kg}^{-1}$ greater than those in the NCEP-NCAR reanalyses (Figure 2(i)). In austral spring (SON) the regional model depicts lower humidity values in Northeast Brazil as compared to the reanalyses, by about $2 \mathrm{~g} \mathrm{~kg}^{-1}$, while over regions such as northern Paraguay, western Amazonia and the Atlantic Ocean off the coast of Northeast Brazil the difference is smaller $\left(\sim 1 \mathrm{~g} \mathrm{~kg}^{-1}\right)$, as shown in Figure 2(1). In general, we can affirm that the mean specific humidity fields over South America in the regional model are of the same order of magnitude as those from the reanalyses, with similar spatial distribution and with some systematic positive or negative biases in some regions. Some of these differences could also be due to the meridional shifts of bands of high specific humidity during the annual cycle, or to the parameterization of the Andes in both the HadRM3P and the NCEP reanalyses (Alves, 2007; Solman et al., 2008).

During DJF, the zonal wind component, as shown in Figure 3(a) and (b), displays intense northeast trade winds in both the NCEP-NCAR reanalyses and the HadRM3P simulations. On the east side of the Andes, a centre of intense zonal wind of about $3 \mathrm{~m} \mathrm{~s}^{-1}$ has been detected to the east of Bolivia. The difference field between the regional model and the reanalyses (Figure 3(c)) shows positive values in northern Amazonia, suggesting that the regional model is underestimating the zonal wind intensity as compared to the reanalyses, by about $3 \mathrm{~m} \mathrm{~s}^{-1}$. In the fall (MAM), Figure 3(d) and (e) indicates that both the regional model and reanalyses capture the trade winds, but to the east of the Andes the regional model shows a weaker flow, by about $3 \mathrm{~m} \mathrm{~s}^{-1}$. The difference map for MAM (Figure 3(f)) clearly displays the underestimation of the zonal wind by the regional model in the tropical region both over the continent and the tropical Atlantic Ocean. In addition, it shows that the regional model simulates less intense easterly flow close to $20^{\circ} \mathrm{S}$ and $55^{\circ} \mathrm{W}$. In winter (JJA, Figure 3(i)), the regional model underestimates the northeast trade winds over northern Amazonia reaching into Bolivia. More intense zonal flow values are observed in the region of the SASH in the regional model (Figure 3(i)), suggesting an intensification of the SASH. In spring (SON), as well as in other seasons of the year, the mean zonal flow from the regional model and the reanalyses tend to be similar, and the difference map (Figure 3(1)) indicates smaller discrepancies in winter than in other periods of the year. While an underestimation of the trade winds is apparent over central Amazonia, an overestimation of the winds coming from the SASH is evident in the south/southeastern regions of Brazil.

The meridional component of the wind during DJF (Figure 4(a) and (b)) shows that the regional model captures the northerly flow over the Amazon and the east side of the Andes, and that the HadRM3P simulates a more intense southerly flow as compared to the reanalyses. The difference maps (Figure 4(c)) show an overestimation of the meridional northerly flow as compared to the NCEP-NCAR reanalyses over Central Brazil. This may be due to the better representation of the topography. The difference map for MAM (Figure 4(f)) exhibits smaller differences in the meridional component of the wind close to the coast of eastern Brazil, suggesting a reduction in the northerly flow and overestimation of the southerly flow over Central Brazil and northern Argentina. During winter (JJA, Figure 4(i)), the largest differences are observed over northern Argentina, where the regional model overestimates the intense southerly flow as compared to the reanalyses (Figure 4(i)). The difference field for SON (Figure 4(1)) shows a stronger southerly meridional flow in the regional model at the southern coast of Brazil, suggesting that in this region the circulation associated with SASH is more intense in the regional model than in the reanalyses.

As for surface pressure, there was close resemblance between the pressure fields in the reanalysis (Figure 5(a)) and the HadRM3P model (Figure 5(b)); moreover no significant seasonal variations were observed in the differences between the NCEP-NCAR reanalyses and the regional model. For this reason, only one figure was prepared, showing the annual average field from 1980 to 1989 . The difference map (Figure 5(c)) shows an underestimate of pressure over a large part of South America in the HadRM3P as compared to the reanalysis. Larger differences are observed over northern Argentina, perhaps due to an overestimation (more intense) of the thermal low pressure in this region by the model (Seluchi et al., 2003). This could contribute to the regional model having a northwesterly flow on the east side of the Andes that is stronger than that found in the reanalysis.

3.2. Variability and characteristics of the SALLJ in the current and future climate using regional modelling

Figure 6 shows the number of SALLJ events detected at Santa Cruz de la Sierra $\left(17.7^{\circ} \mathrm{S}, 63^{\circ} \mathrm{W}\right)$, using the modified Bonner criteria 1 specified in Section 2.3, for both present and future climate. It is observed that in the current climate the SALLJ annual cycle derived from the reanalyses reaches a maximum in DJF, while the simulated maximum in the annual cycle from the HadRM3P occurs in JJA. For the model, the annual cycle is similar in both the present and the future, with the maximum occurring in JJA and the minimum in SON. For the present it is similar to that simulated in the global warming scenario for the end of the 21st century.

A comparison among the simulated cases for the present and for the future shows that during DJF, the number of SALLJs detected goes from 45 for the present 
(a)

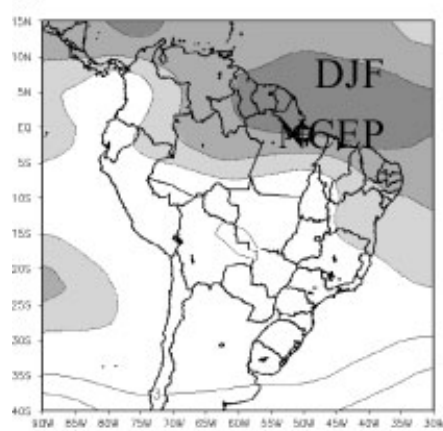

(d)

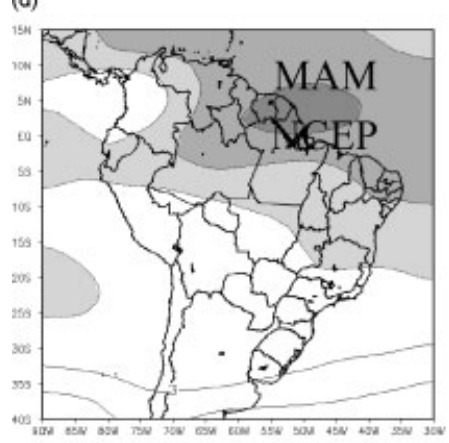

(g)

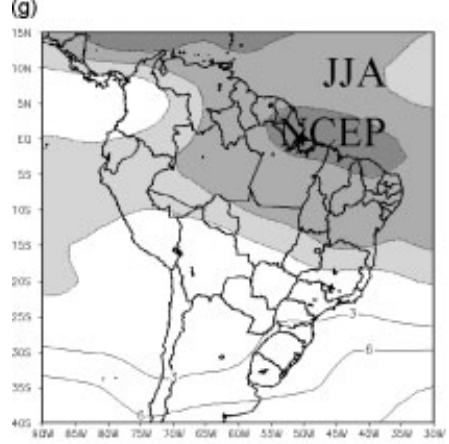

(j)

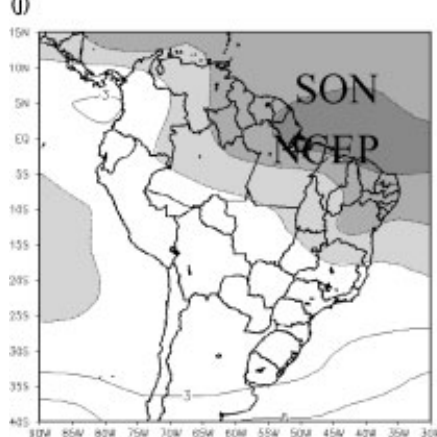

(b)

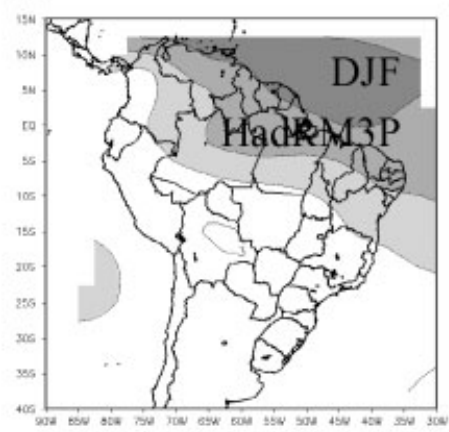

(e)

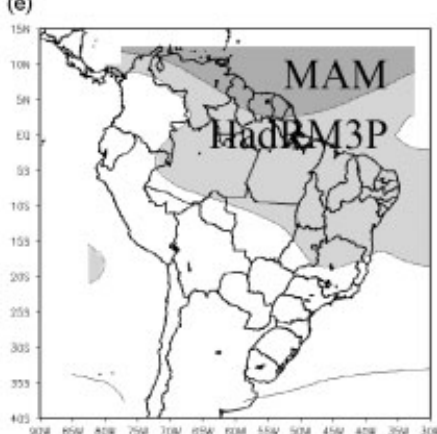

(h)

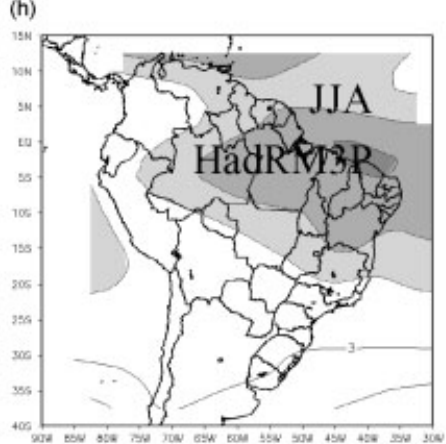

(k)

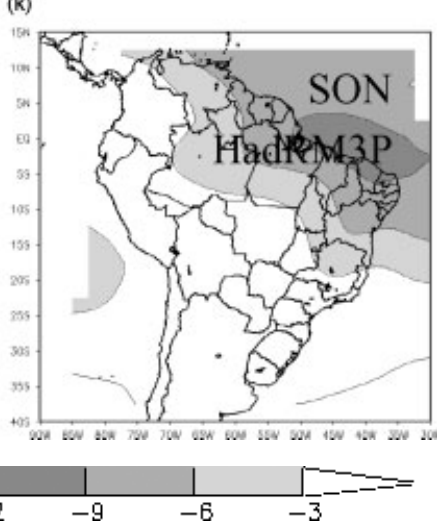

(c)

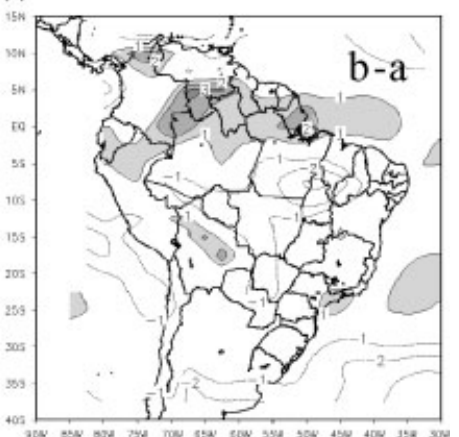

(f)
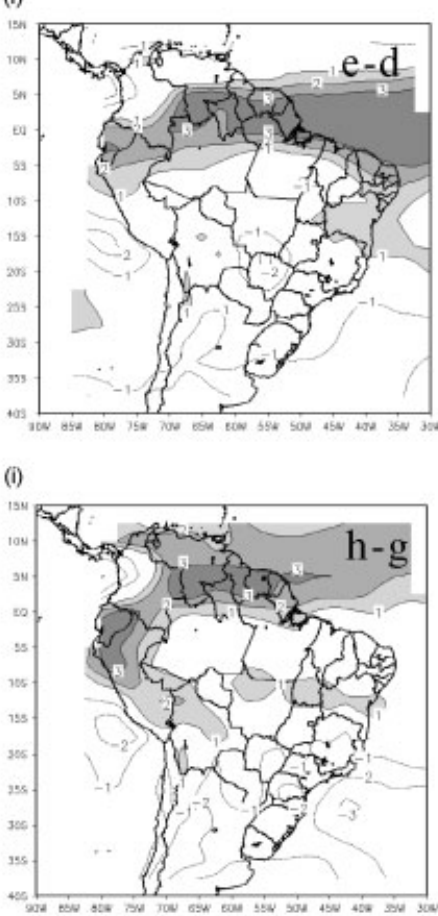

(l)

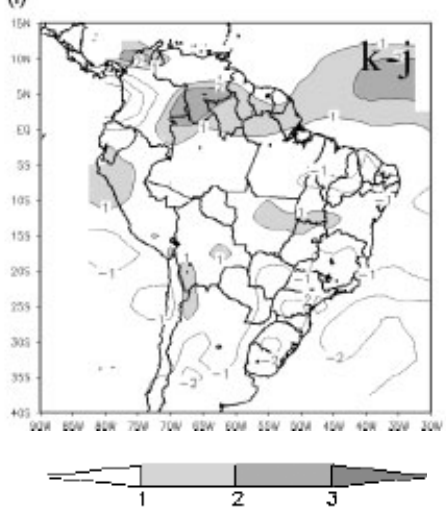

Figure 3. Fields of zonal wind below $700 \mathrm{hPa}$. Figures (a) (DJF), (d) (MAM), (g) (JJA) and (j) (SON)) were obtained from NCEP reanalyses for the 1980-1989 period. Figures (b) (DJF), (e) (MAM), (h) (JJA) and (k) (SON) were obtained from HadRM3P for same period. Figures (c),

(f), (i) (e) (l) are the difference fields between (b) and (a), (e) and (d), (g) and (h), (e) (k) and (j) respectively. Units are $\mathrm{m} \mathrm{s}^{-1}$.

to 78 in the A2 scenario. This is an increase of about $73 \%$ in the occurrence of SALLJs in the climate of warming in SRES A2. On the other hand, during MAM the number of SALLJs detected is very close, 37 cases in the current climate versus 43 in the A2 scenario (an increase of about $16 \%$ ). In JJA, the number of SALLJs varies from 62 in the present to 88 in the A2 scenario, which is equivalent to an increase of $41 \%$. In SON more SALLJs are detected in the future climate than in the present. The number decreases from 25 to 15 , that is during this period, the number of SALLJs is about $60 \%$ smaller in the SRES A2 from 2080 to 2089 as compared to the present. This 
(a)

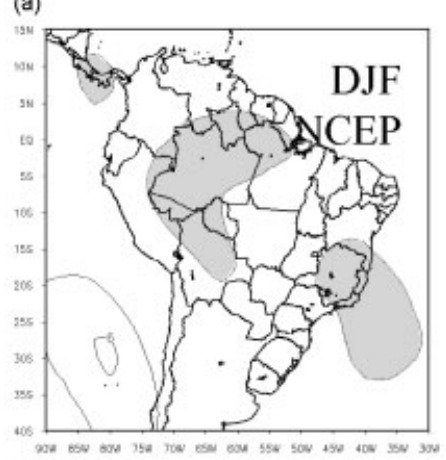

(d)

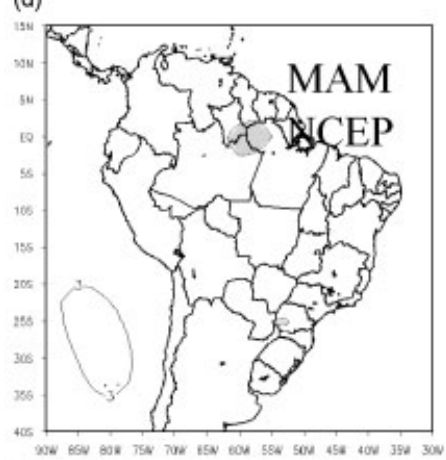

(g)

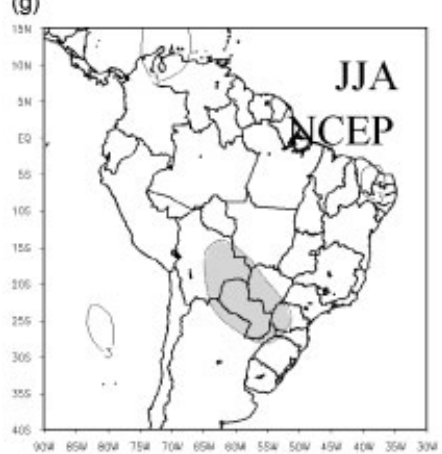

(j)

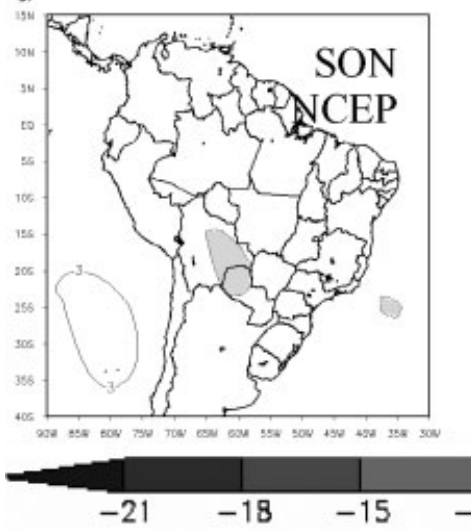

(b)

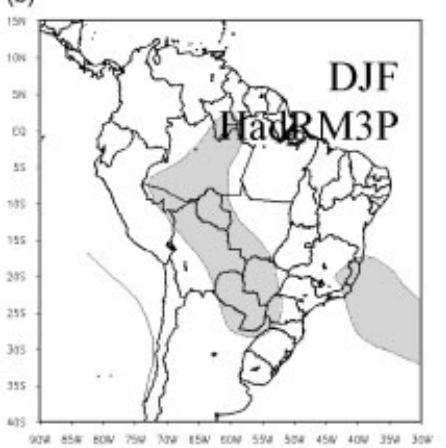

(e)

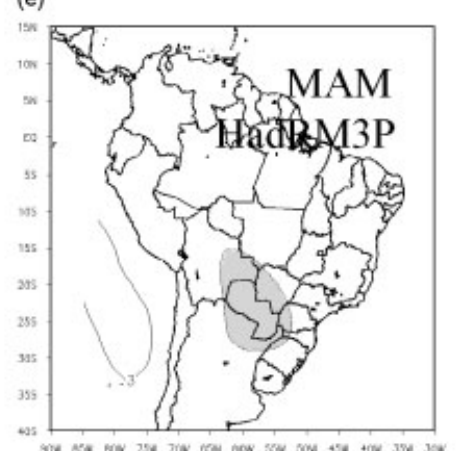

(h)

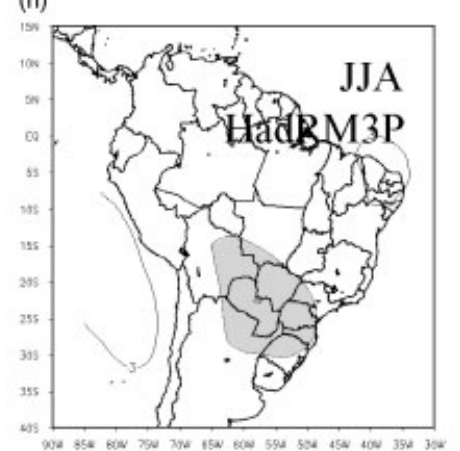

(k)

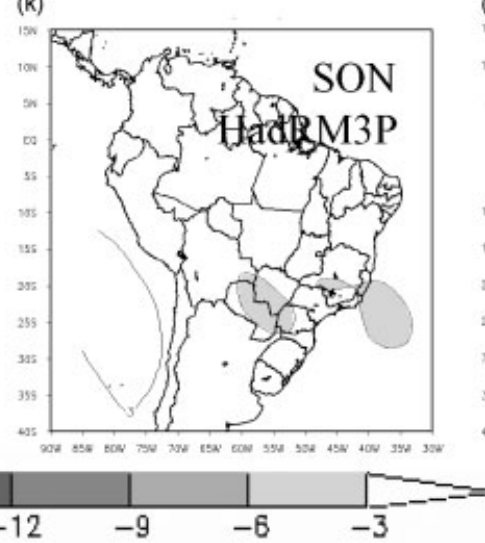

(c)

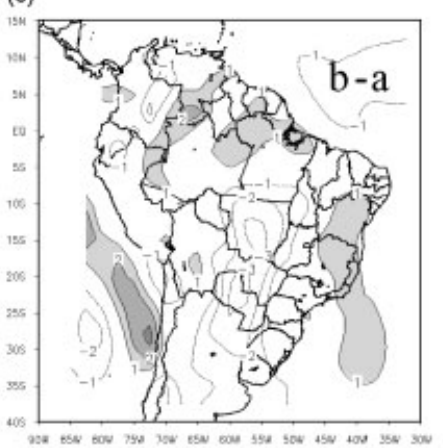

(f)

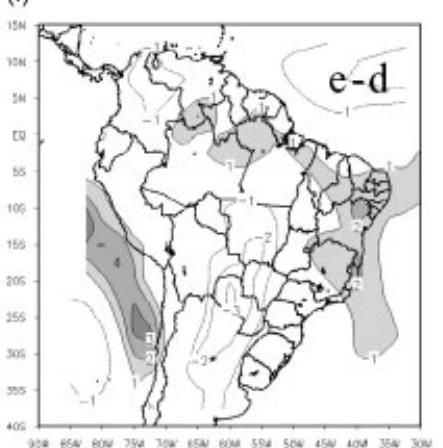

(i)

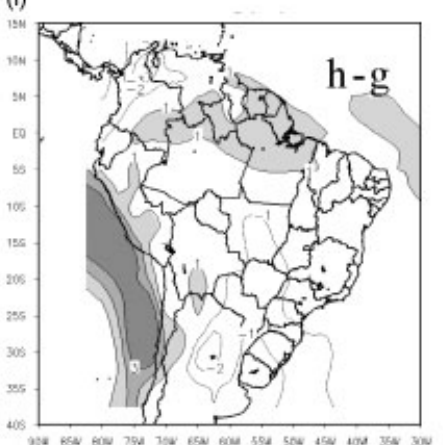

(1)

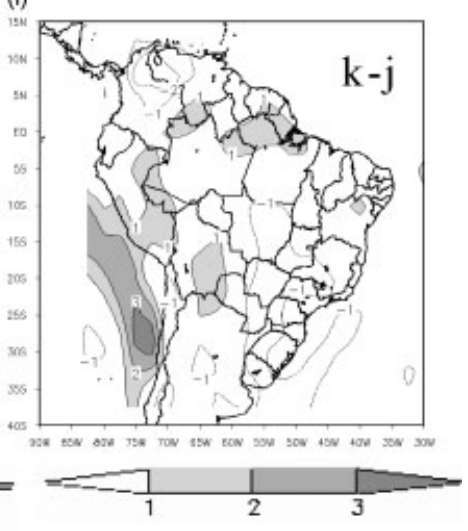

Figure 4. Same as in Figure 3, but for meridional wind component.

decrease of the number of SALLJs may be associated with the decrease of the vertical wind shear in this period and would suggest a vertical stretching of the jet axis.

The total number of cases of detected jets using the HadRM3P model simulations was 169 between 1980 and 1989, and 224 between 2080 and 2089. The 55 additional cases of SALLJ events detected in the global warming climate can be considered an indicator of an intensification of the regional circulation and the SALLJs, with the jets more frequent and possibly faster than in the present, especially during summer and spring. This would have impacts in the regimes of extreme rainfall events at the exit region in the La Plata region, and in fact, the number of intense rainfall events in southern and 
(a)

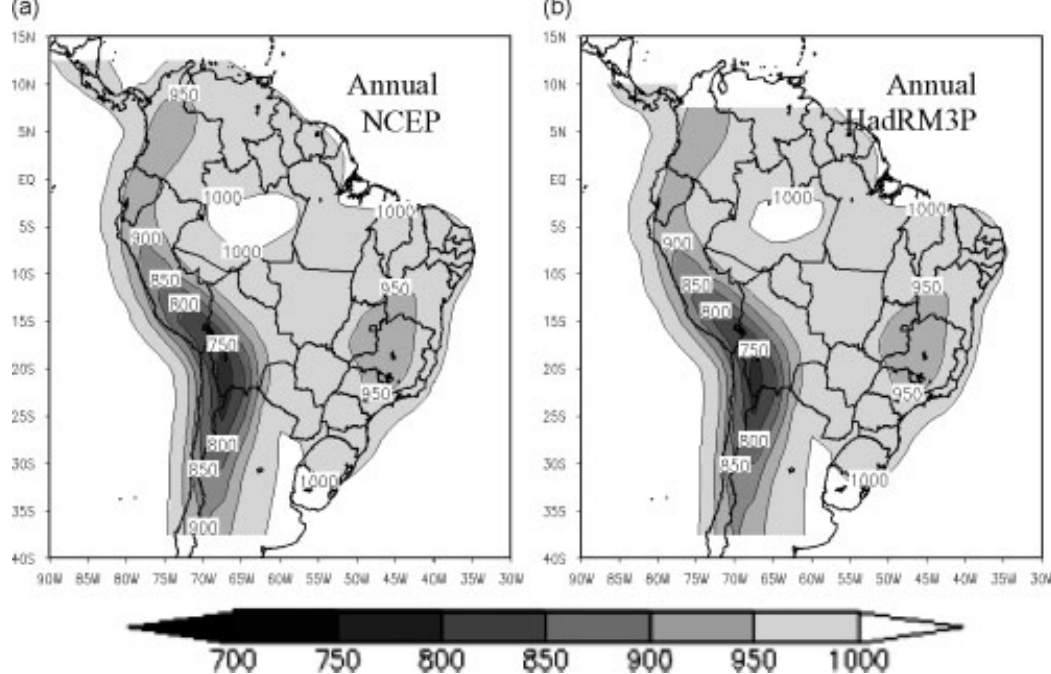

(c)

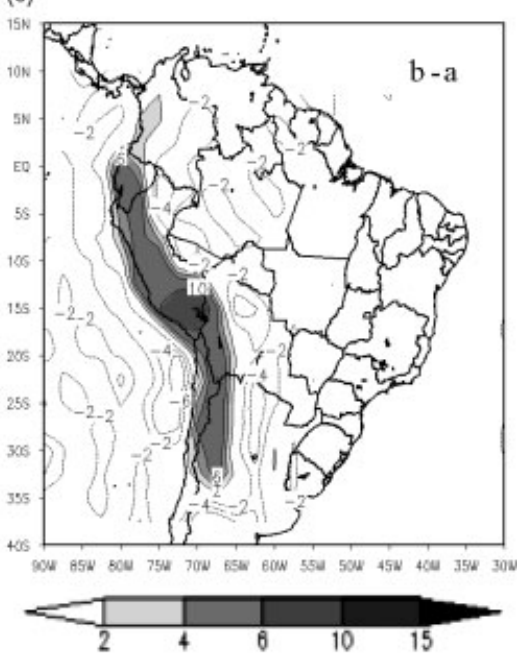

Figure 5. Average annual surface pressure, obtained from: (a) NCEP reanalyses for the 1980-1989 period; (b) HadRM3P for the same period; and (c) the difference between (b)-(a). Units are in $\mathrm{hPa}$.

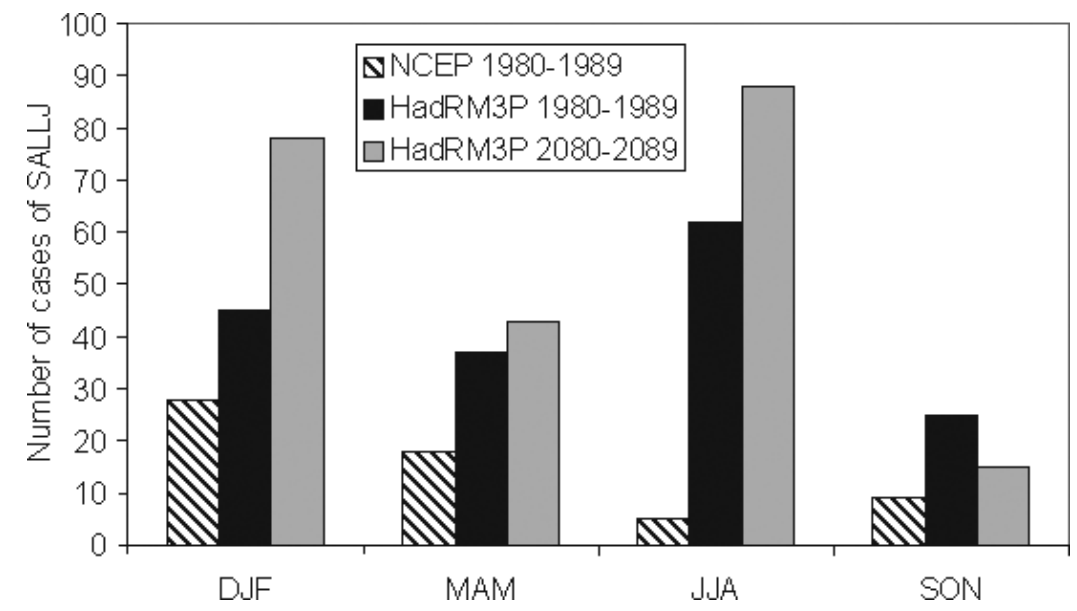

Figure 6. Number of detected SALLJs in Santa Cruz de la Sierra in Bolivia $\left(17.7^{\circ} \mathrm{S}, 63^{\circ} \mathrm{W}\right)$ using the modified Bonner criteria 1.

southeastern Brazil has increased during the last years (Marengo et al., 2007). It is important to mention that for the present climate 1980-89, the modified Bonner criteria 1 were applied for the four seasons in the NCEP-NCAR reanalysis circulation fields. The results indicate that 28 cases of SALLJs were obtained during DJF, 18 in MAM, 5 in JJA and 9 in SON with a total of 60 detected jets from 1980 to 1989, as compared to 169 simulated for the HadRM3P model during 1980-89. This indicates that the model tends to overestimate the number of SALLJ events in the present, and the different resolutions of the regional model and the reanalyses could be the main cause. However, based on the model results only, an increase of $25 \%$ in the number of SALLJ events is noticed in the warmer climate, especially in summer, where the increase reaches $72 \%$.

Figure 7(a) and (b) shows the wind speed at the $850 \mathrm{hPa}$ level, as well as values of the vertical wind shear between the 850 and $700 \mathrm{hPa}$ levels. Figure 7 shows an overestimation of the wind and of the vertical shear in relation to the NCEP-NCAR reanalyses. This overestimation could be due mainly to the difference in resolution between the regional model and the reanalyses.

In regard to the magnitude of the mean wind field, a seasonal variability with higher values can be observed during JJA and lower values during MAM for both current and the future climates in the SRES A2 scenario. In the present and future climate, the average of vertical wind shear has values lower than $3 \mathrm{~m} \mathrm{~s}^{-1}$.

In Figure 7(b), for the SALLJ composite, after the application of the modified Bonner criteria 1, an increment is observed in the wind speed and vertical wind shear as compared to the climatology. The values of the horizontal wind over Santa Cruz de la Sierra can be higher than $20 \mathrm{~m} \mathrm{~s}^{-1}$ during JJA. It is also observed that the vertical wind shear in the SALLJ composite reaches values of about $8 \mathrm{~m} \mathrm{~s}^{-1}$ (Figure 7(b)). This shows that the regional model used in this study detected cases of SALLJs that satisfy even the modified Bonner criteria 1, as in the SALLJ event that occurred during December 2003 in the SALLJ field experiment (Vera et al., 2006c) and was studied by Saulo et al. (2007). 

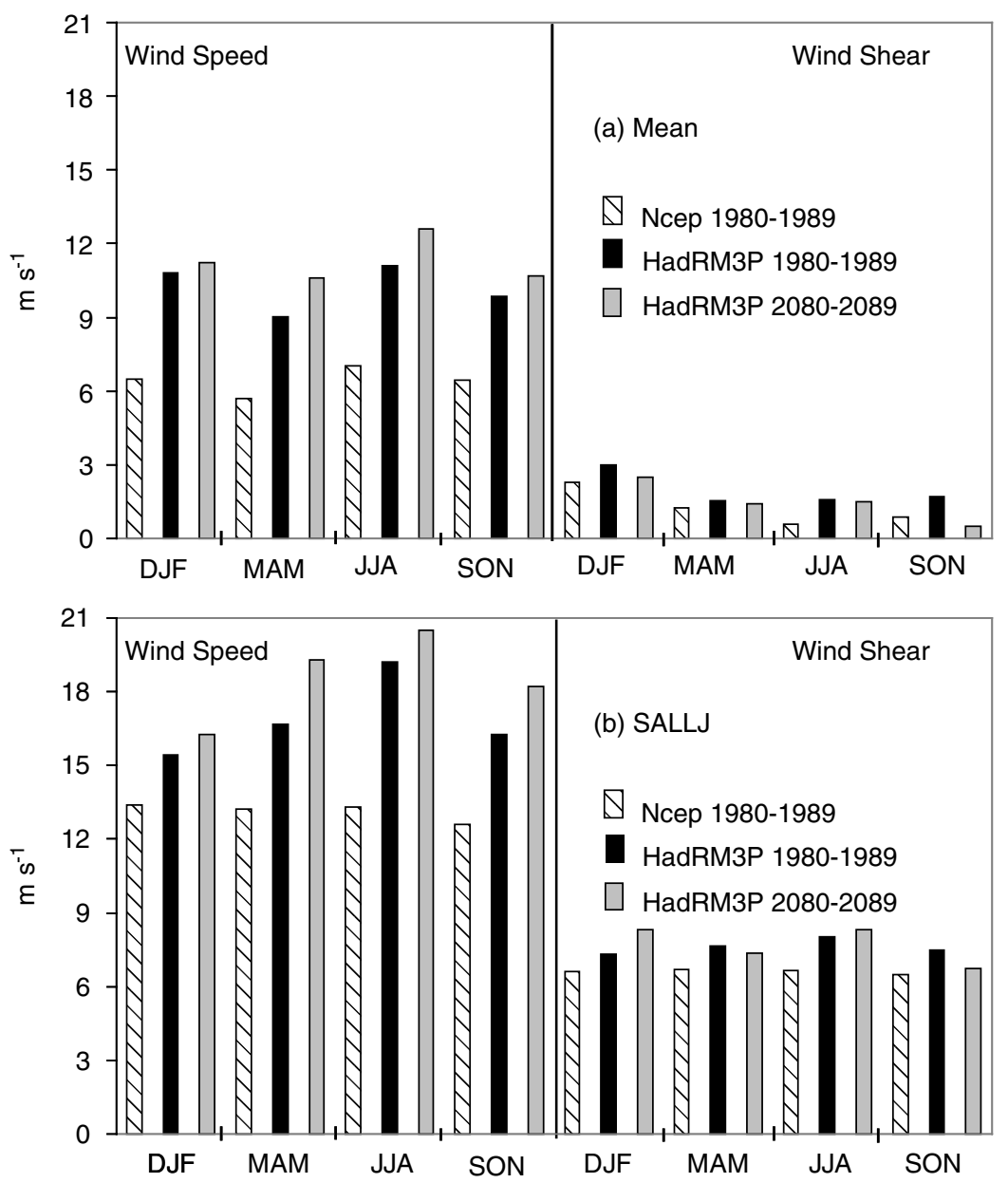

Figure 7. Magnitude of the wind at $850 \mathrm{hPa}$ and vertical wind shear between the 850 and $700 \mathrm{hPa}$ levels. (a) Average and (b) composite of SALLJ events. Units are $\mathrm{m} \mathrm{s}^{-1}$.

Figure 7 shows an intensification of the wind speed observed in the global warming climate. The increase of the jet speed in the future scenario can be associated with an intensification of the thermal gradient between tropical and subtropical South America, as shown by Ambrizzi et al. (2007) and Marengo et al. (2007). There are indications that the thermal Chaco low would be intensified in a warmer climate and this would increase the meridional pressure gradient, increasing the intensity of the SALLJ. Uccellini and Johnson (1979) related the presence of the high-level jets to the formation of LLJs east of the mountains. In a warming climate, the more intense SALLJ activity could be also associated, through the adjustment of mass, with the intensification of the maximum speed of the upper-level subtropical jet.

\subsection{Meridional moisture transport associated with the} SALLJ

Figure 8 shows a vertical cross section of the meridional moisture transport fields for the SALLJ composite along the latitude of Santa Cruz de la Sierra $\left(17.7^{\circ} \mathrm{S}\right)$. From summer to fall, a larger meridional moisture transport is detected mainly in the core of the SALLJ $\left(\sim 63^{\circ} \mathrm{W}\right)$ in the global warming high-emission scenario A2, as compared to the current climate. The set of panels from
Figure 8 shows that in relation to the vertical structure of the meridional moisture transport, in the global warming scenario, moisture transport is intensified towards the east as well as with height. In the global warming climate, the meridional moisture transport can be higher by $60 \mathrm{~m} \mathrm{~g}$ $\mathrm{s}^{-1} \mathrm{~kg}^{-1}$ next to the Andes as compared to the present. Furthermore, in addition to the core region of strong northerly moisture transport of the SALLJ during DJF and SON, a secondary nucleus is observed, linked to the moisture transport from the South Atlantic Ocean, with a large northerly meridional moisture transport located between 40 and $55^{\circ} \mathrm{W}$ in the current climate as well as in the global warming scenario.

For present climates, Saulo et al. (2000), Nicolini et al. (2002) and Marengo et al. (2004) have detected this secondary nucleus as corresponding to the northerly flow associated with the SASH, whose moisture transport is more intense during winter.

Also, the SASH is stronger and closer to the continent during that season, and the elevated topography in this 'Planalto' region would also have a channelling effect on the wind. The more intense meridional moisture transport is detected at about $63^{\circ} \mathrm{W}$ and is larger (about $30 \mathrm{~m} \mathrm{~g}$ $\mathrm{s}^{-1} \mathrm{~kg}^{-1}$ ) in the warming scenario. This can be explained by examining Figure 8 , which shows the characteristics 
(a)

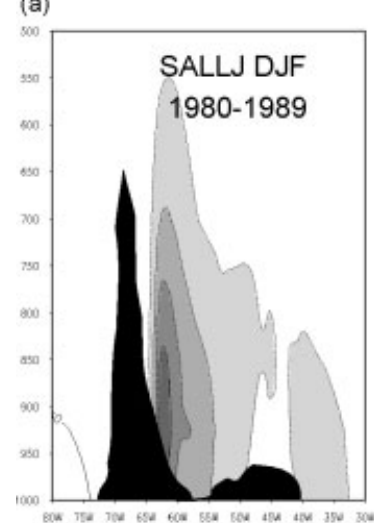

(e)

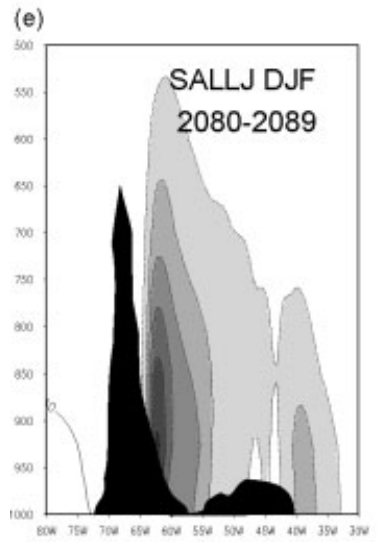

(b)

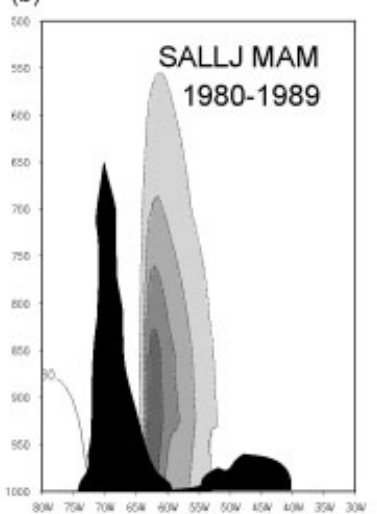

(f)

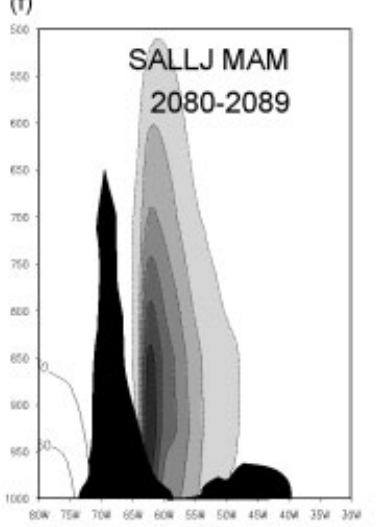

(c)

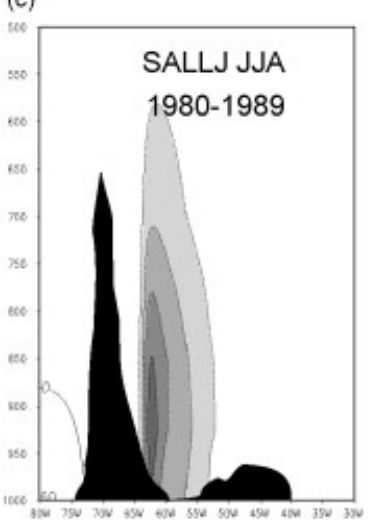

(g)

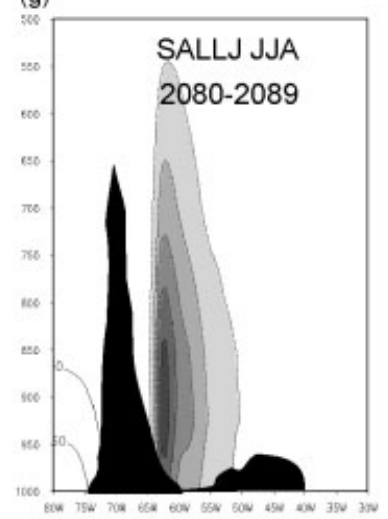

(d)

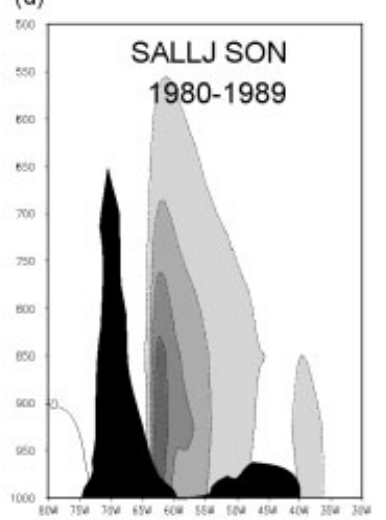

(h)

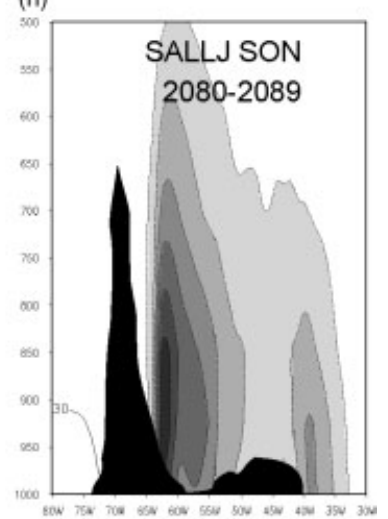

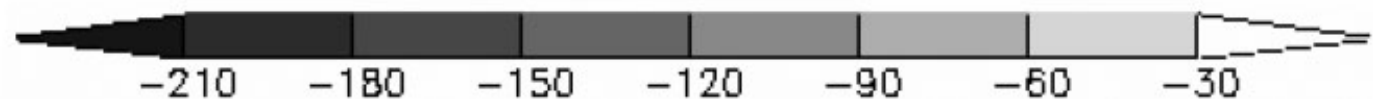

Figure 8. Vertical cross section of the meridional moisture transport along the latitude of Santa Cruz de la Sierra in Bolivia (17.7 $\left.{ }^{\circ} \mathrm{S}\right)$. Units are $\mathrm{m} \mathrm{s} \mathrm{s}^{-1} \mathrm{~kg}^{-1}$.

of each component of this moisture transport along the Santa Cruz de la Sierra latitude.

Figure 9 shows that the regional model positions the core of the SALLJ between 60 and $63^{\circ} \mathrm{W}$, a location very similar to that shown by Marengo et al., 2004, who used 50 years of NCEP-NCAR data in his study of this jet. Moreover, the values of northerly wind components of around $10-12 \mathrm{~m} \mathrm{~s}^{-1}$ and of specific humidity that vary between 15 and $21 \mathrm{~g} \mathrm{~kg}^{-1}$, in the lower atmosphere, are quite close to those shown by Marengo et al., 2004 who utilized the data from the NCEP-NCAR reanalyses.

In the global warming scenario, for the period of DJF (Figure 9(e)) there appears to be a higher moisture content from the surface to $700 \mathrm{hPa}$ between 60 and $45^{\circ} \mathrm{W}$, as compared to the present (Figure 9(a)), while the intensity of the meridional component of the wind in the lower levels of the atmosphere is weaker. This is emphasized by Figure 7(b), which shows wind speeds smaller than $1 \mathrm{~m} \mathrm{~s}^{-1}$ at $850 \mathrm{hPa}$ over Santa Cruz de la Sierra. So, the intense moisture transport that is revealed in the global warming scenario is due to the intensification of the moisture content rather than to the intensification of the winds.

During MAM, a higher moisture content concentrated near the Andes is detected in the global warming scenario (Figure 9(f)) as compared to the current climate
(Figure 9(b)). Also, the wind is stronger (see Figure 7(b)) and with a larger contribution to the meridional moisture transport (Figure 8(f) compared to Figure 8(b)).

For JJA, Figure 9(c) and (g) shows the patterns of wind and moisture simulated for the present and projected for the future, respectively. The main difference between them is in the magnitude of the moisture content and wind intensity, with the exception of a nucleus of higher moisture content on the east side of the Andes.

On the other hand, for SON, Figure 9(h) shows that there is a larger contribution of the wind speed (meridional component) as compared to the contribution of moisture content in the global warming scenario versus present climate (Figure 9(d)). This is consistent with the meridional moisture transport shown in Figure 8(d) and (h). A nucleus of large moisture content is observed in lower levels around $850 \mathrm{hPa}$ in the global warming scenario (Figure 9(h)) as compared to the present climate (Figure 9(d)). This increase in the moisture content in the global warming climate scenario extends from the lower levels to $\sim 700 \mathrm{hPa}$ and is able to affect the moisture that moves from tropical regions east of the Andes to the La Plata Basin. This is discussed in the next section.

Therefore, it could be suggested that the higher moisture transport carried out by the SALLJ in a global warming scenario (set of Figure 8) might be due to the higher 
(a)

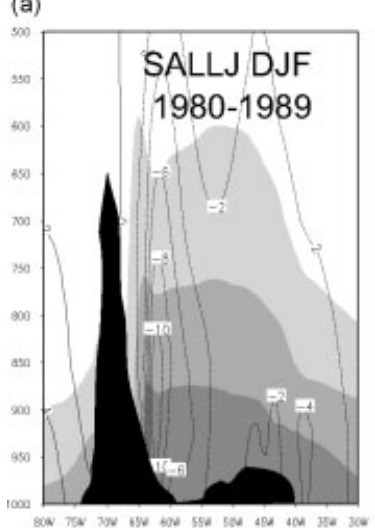

(e)

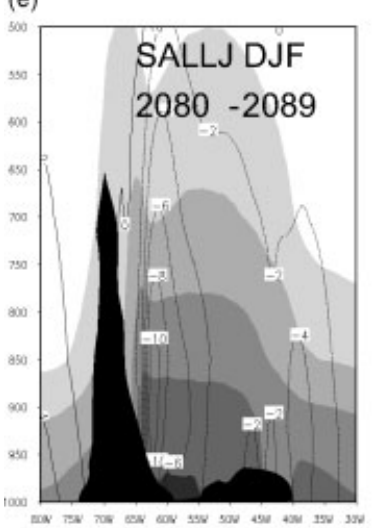

(b)

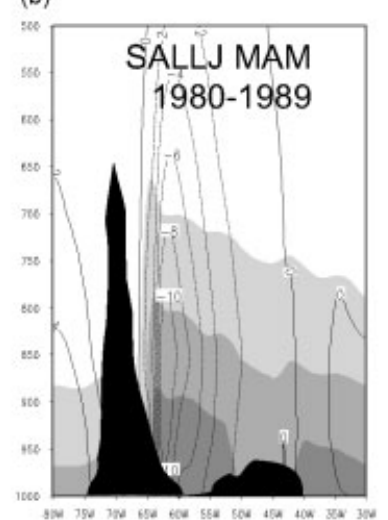

(f)

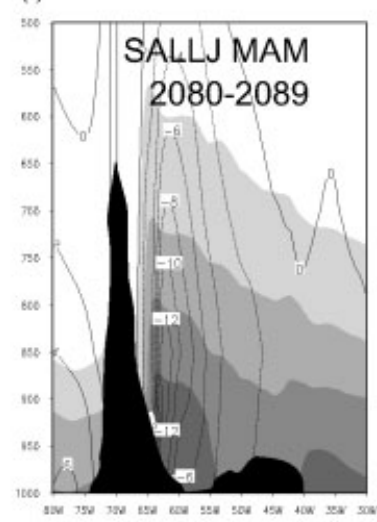

(c)

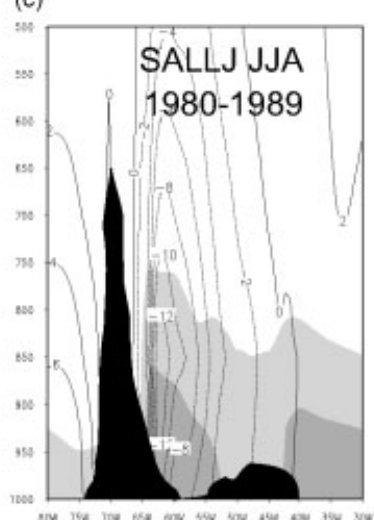

(g)

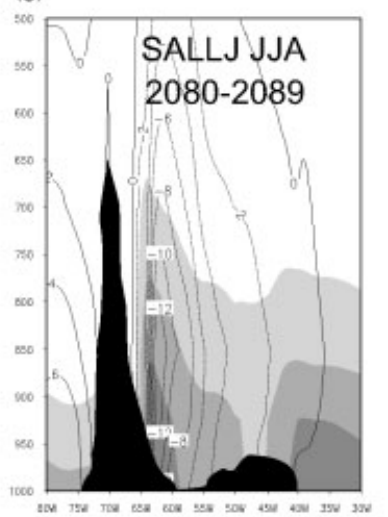

(d)

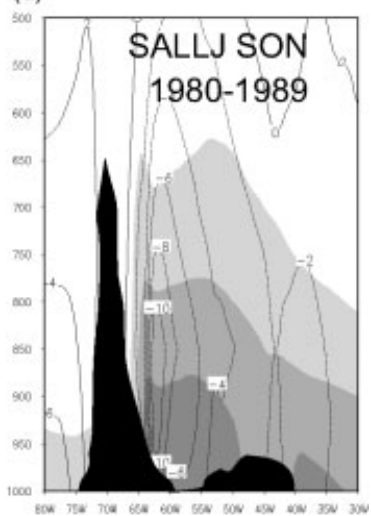

(h)

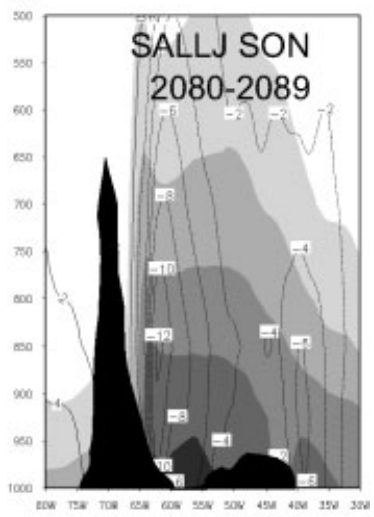

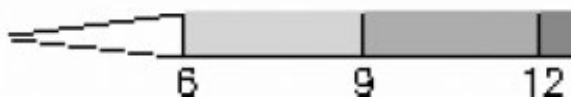

\section{2}

15

18

21

Figure 9. Vertical cross section of the meridional component of the wind $\left(\mathrm{m} \mathrm{s}^{-1}\right)$ and specific humidity $\left(\mathrm{g} \mathrm{kg}^{-1}\right)$ along the latitude of Santa Cruz de la Sierra in Bolivia $\left(17.7^{\circ} \mathrm{S}\right)$.

wind speed and the larger moisture content in the lower levels of the atmosphere. It is important to highlight that the large wind speed at the low levels of the atmosphere in the global warming scenarios has been detected in all seasons but there are differences in the intensity of the wind in the annual cycle, as shown in Figures 7 and 9. The large amounts of moisture in the lower levels of the atmosphere detected in the global warming scenario as compared to the present climate may affect the magnitude and the seasonal variability of the meridional moisture transport. The DJF season is an example of a situation in which the moisture content at the lower levels east of the Andes seems to contribute more than the wind speed to moisture transport, as shown in Figure 9(e) (warming scenario) versus Figure 9(a) (present climate).

3.4. Moisture flux at the lateral borders of the areas under study for present and global warming scenarios

In this section we make a comparison between the simulated mean integrated fluxes for the present and the future, already described in Section 2.5. The analysis is shown in Figures 10-13: Figure 10(a) and (b) (DJF), 11(a) and (b) (MAM), 12(a) and (b) (JJA) and 13(a) and (b) (SON). During summer in the present climate, Nicolini et al. (2002) used the Eta/CPTEC regional model and obtained a value of $-1.9 \times 10^{-8} \mathrm{~kg} \mathrm{~s}^{-1}$ for the northerly flux crossing the latitude of $20^{\circ} \mathrm{S}$ along $45^{\circ} \mathrm{W}$ and $64^{\circ} \mathrm{W}$, which represents the northern border of a box in the La Plata region. For the same latitudinal border, and also using the Eta/CPTEC regional model, Saulo et al. (2000) obtained $-1.9 \times 10^{-8} \mathrm{~kg} \mathrm{~s}^{-1}$ for the summer period and $-1.84 \times 10^{-8} \mathrm{~kg} \mathrm{~s}^{-1}$ for spring, integrating the flows from the surface to $800 \mathrm{hPa}$. These values are very close to the ones obtained by HadRM3P on the border NP from the present-climate simulation.

Our analysis is focused along the lateral borders of the boxes representative of the Amazon (A) and the La Plata Basin (P). In DJF (comparison between Figure 10(a) and (b)) on the NA border in SRES A2, the moisture flux is $64 \%$ greater than for the present climate. On the border of EA, a similar increase in moisture flow increase is observed. On the border of WA there is an increase of about $45 \%$ in the intensity of the westerly flux in the global warming scenario as compared to the present. On the border of SA the moisture flux increases by $75 \%$ in the future. During MAM (Figure 11(a) and (b)) and SON (Figure 13(a) and (b)), an intensification is also detected in the moisture flux that enters across the EA and NA borders and that leaves across the WA and SA borders in the future. In contrast, in JJA, Figure 12(a) (current climate) exhibits a southerly flow entering across the SA 


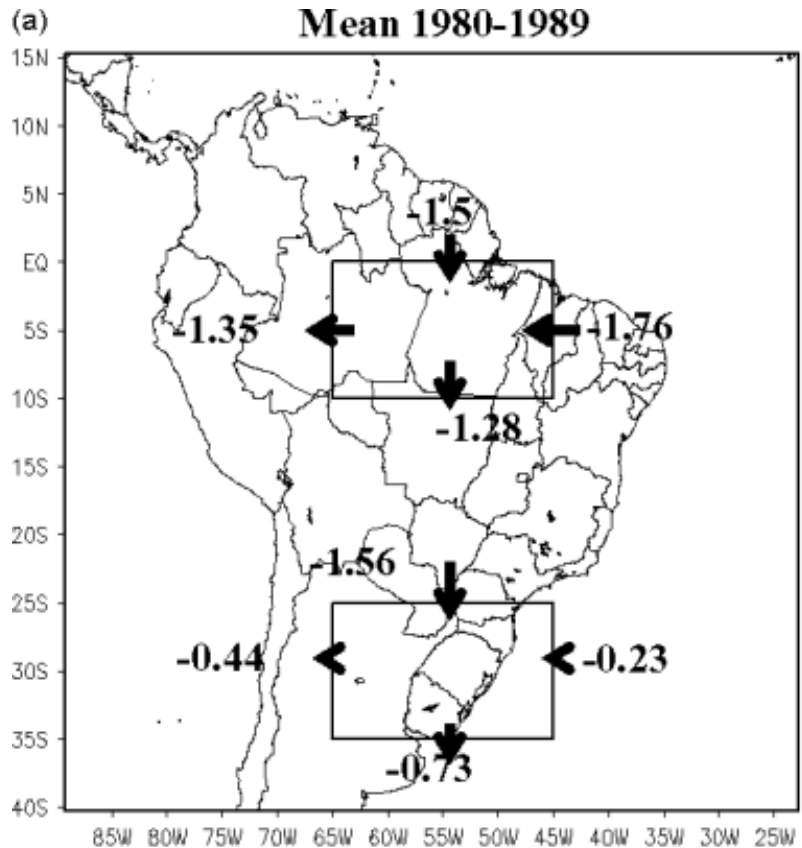

(c)

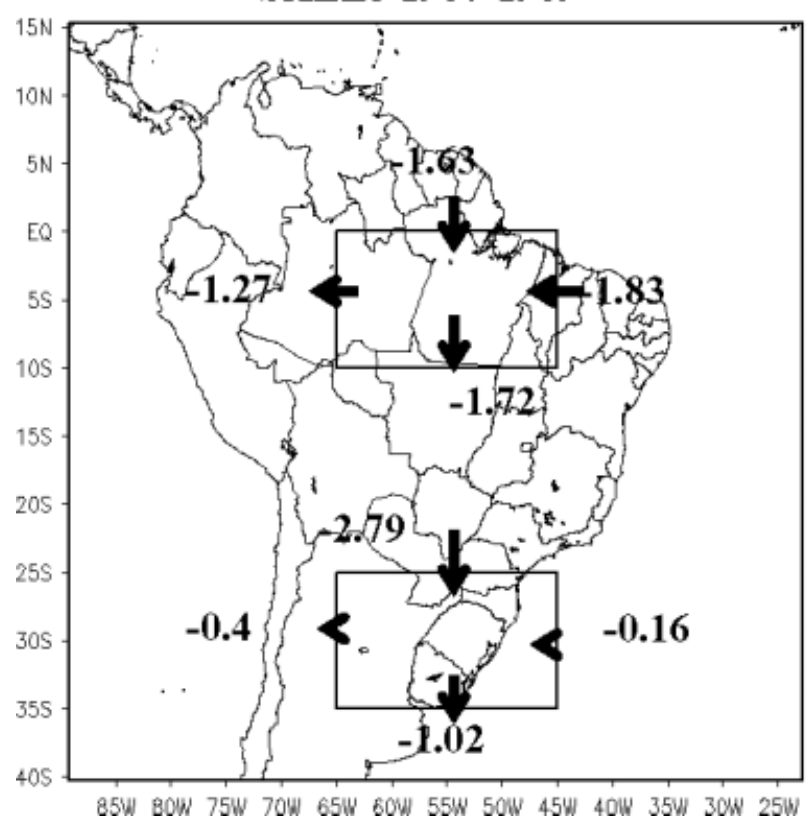

(b)

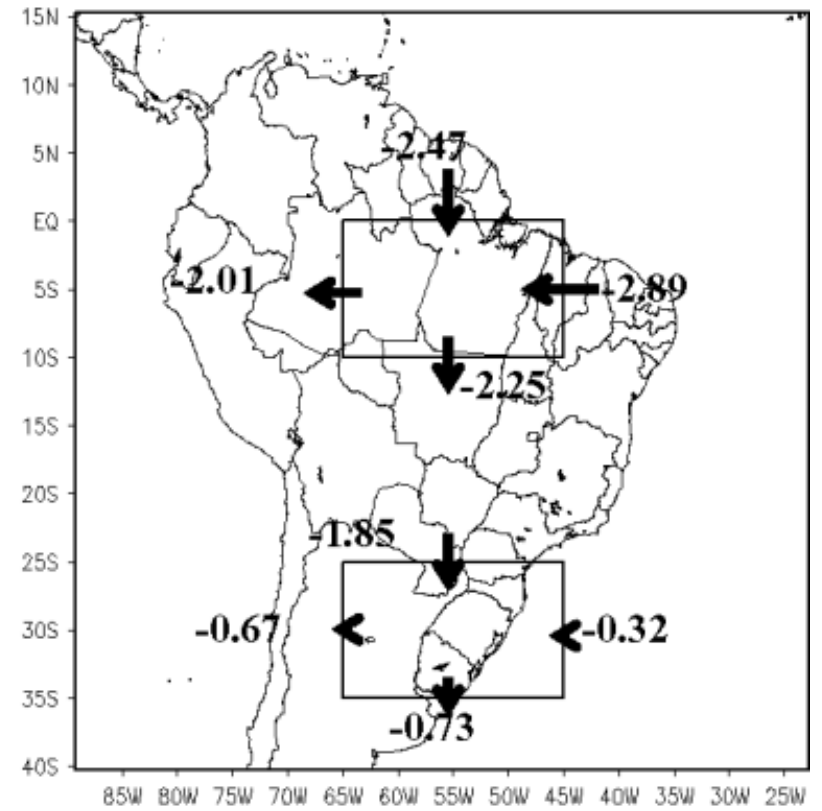

(d)

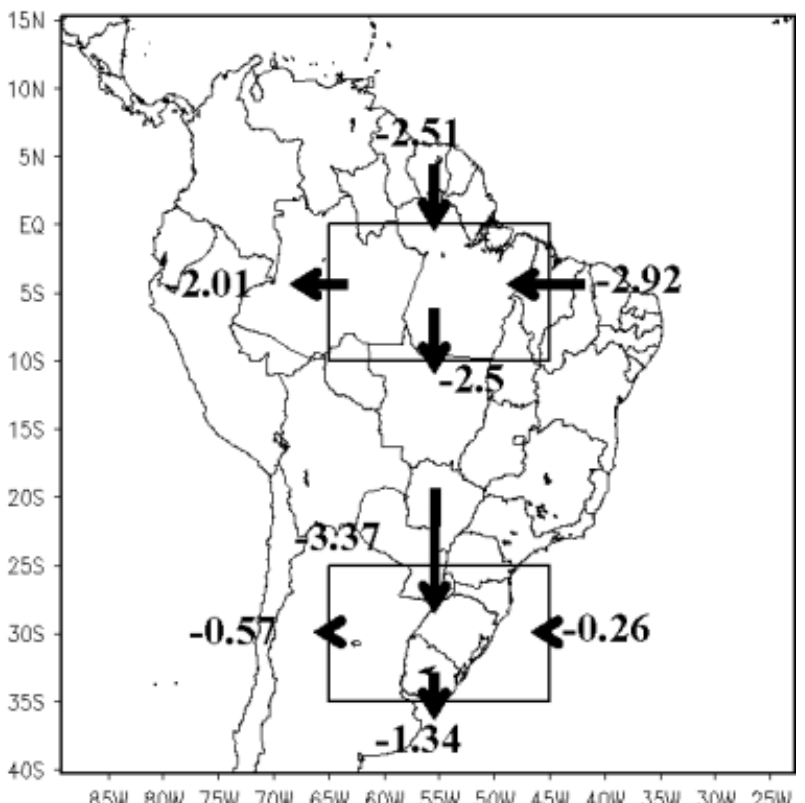

Figure 10. Components of the moisture flow integrated along the lateral boundaries of representative areas of the Amazon and La Plata basins during DJF. The numbers in the centre of the rectangles represent the horizontal moisture divergence. Units are $\times 10^{8} \mathrm{~kg} \mathrm{~s}^{-1}$.

border and leaving the box across the NA border. This occurs because the meridional component of the trade winds comes from the south over the continent, at a time of the year when the SASH is more intense and closer to the continent (Marengo et al., 2004).

At the lateral borders of the La Plata Basin, an intensification of the flux that penetrates across the northern border NP in the global warming scenario is detected. During DJF there is an increase of $\sim 50 \%$ in the lower atmosphere moisture flux in the SRES A2 global warming scenario across the NP border. In other seasons, an intensification of the northerly flux across the NP border in a global warming scenario is also observed.
For MAM, the flux increases by $+58 \%$, for JJA $+44 \%$ and in SON it increases $+72 \%$.

In what follows we discuss the influence of the presence of the SALLJ on the moisture flux between the $\mathrm{A}$ and $\mathrm{P}$ regions. In the current climate and comparing the mean present climate and the SALLJ composites during DJF, an intensification of the moisture penetration into the region of the La Plata Basin is observed on the border NP that is approximately equivalent to an increase of $60 \%$ in the northerly flux in the summer SALLJ composite as compared to the summer mean. For MAM, JJA and SON the same pattern is detected for the SALLJ composite, suggesting an intensification of the moisture 
(a)

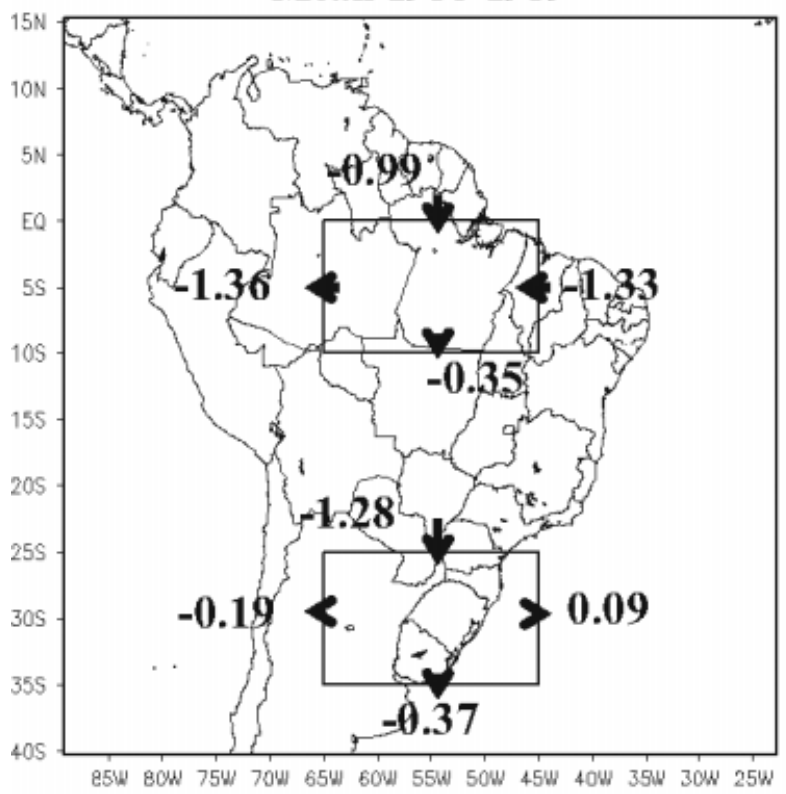

(c)

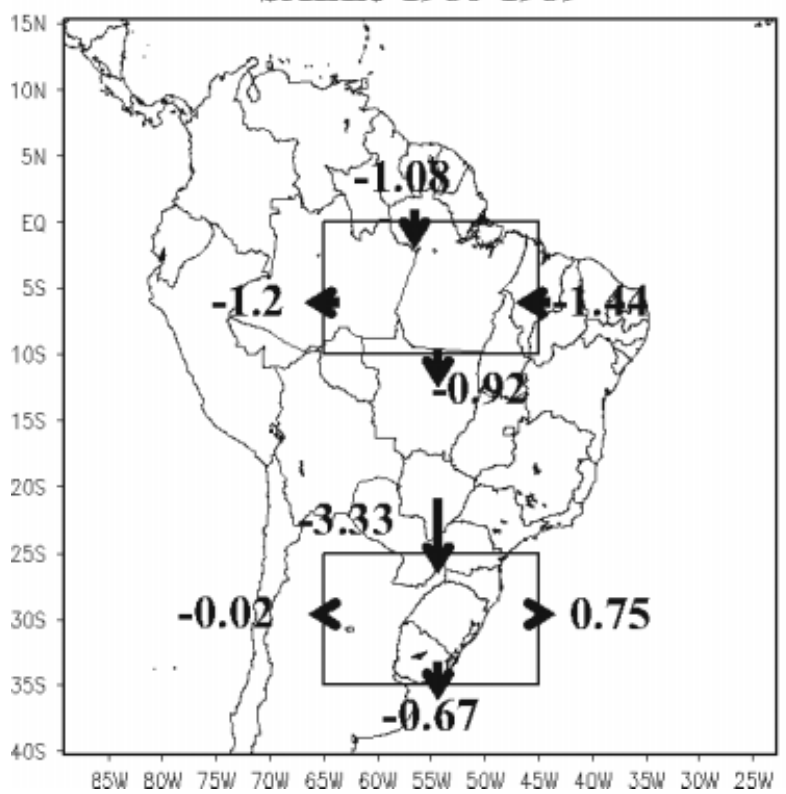

(b)

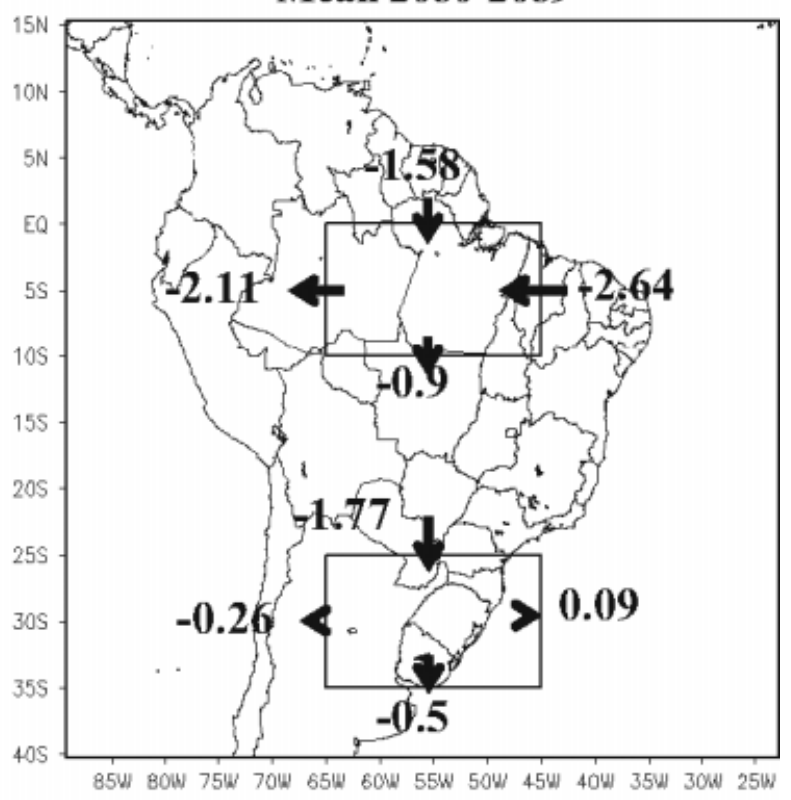

(d)

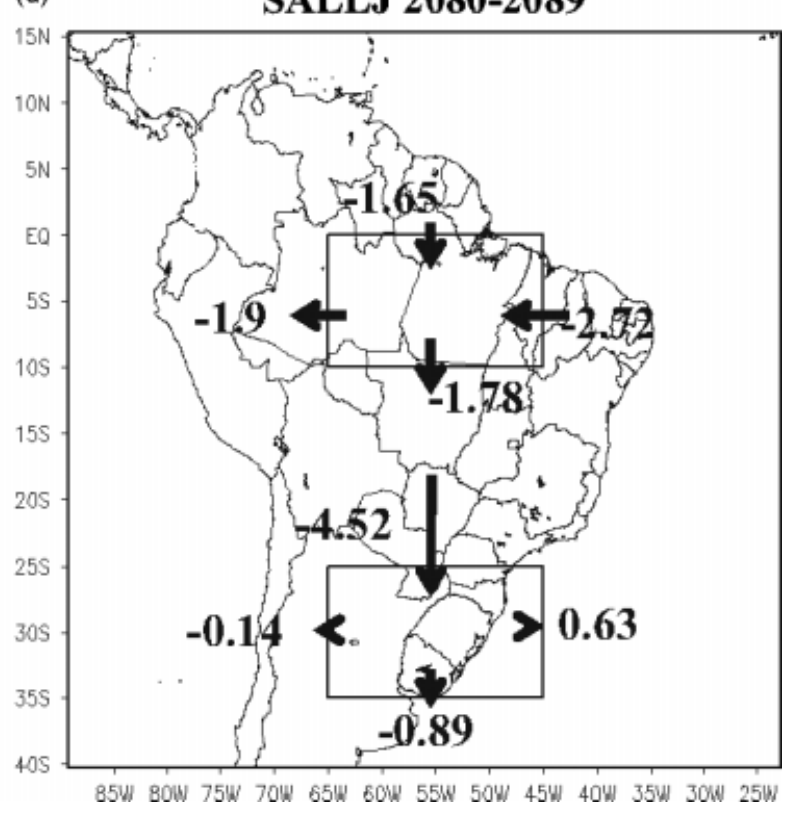

Figure 11. Same as in Figure 10 but for MAM.

flux on the NP border in the SALLJ composite. In MAM an increase of about $136 \%$ was observed. In JJA the value becomes about $120 \%$ higher. In spring (SON), the SALLJ composite shows an increase of $170 \%$ as compared to the spring mean.

The SALLJ in the current climate accelerates the moisture transport to the east of the Andes. That increases the moisture flux towards the La Plata Basin, as shown in various studies. The northerly flux of $-3.85 \times 10^{-8} \mathrm{~kg} \mathrm{~s}^{-1}$ entering the La Plata Basin at $20^{\circ} \mathrm{S}$, derived by Nicolini et al. (2002) compares favorably with the estimates of $-3.14 \times 10^{-8} \mathrm{~kg} \mathrm{~s}^{-1}$ at the same border, derived from the HadRM3P for 1980-89, as shown in Figure 10(c).

In the global warming scenario, there is an increase in the moisture flux that crosses the northern boundary NP.
During DJF, this value increases by $47 \%$. During MAM, the increase reaches about $111 \%$, while during JJA the increase is about $103 \%$, and during SON, the increase reaches about $156 \%$.

The moisture flux in the SALLJ composite in a global warming scenario shows a more intense flow from the tropical region into the northern border NP of the La Plata Basin, east of the Andes (Figure 10). In the global warming scenario, Figures 10(d), 11(d), 12(d) and 13(d) show higher moisture flux crossing the NP border when compared to the present climate (Figures 10(c), 11(c), 12(c) and 13(c)). The SALLJ composite for DJF shows an increase in the moisture flux of about $40 \%$. In MAM, this increase is about $41 \%$. In JJA, the increase is about $33 \%$, while in spring (SON), the moisture flux value 
(a)

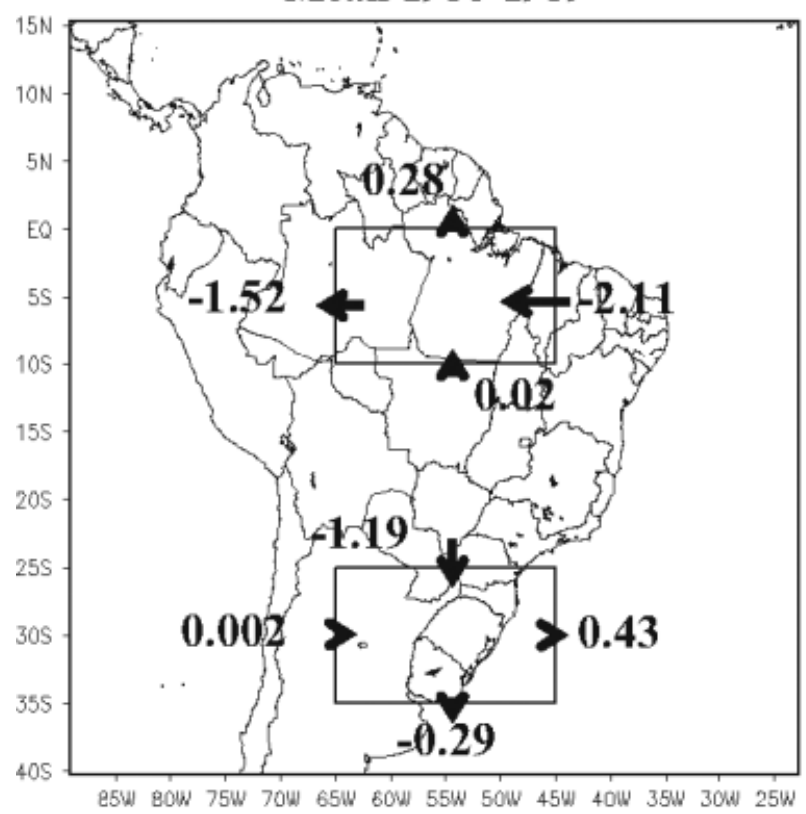

(c)

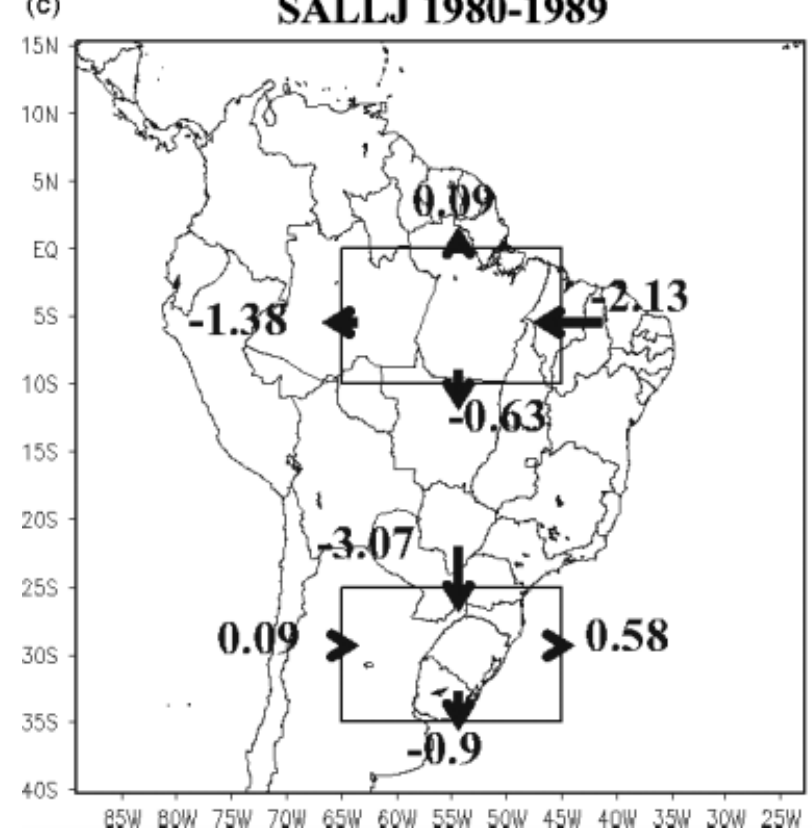

(b)

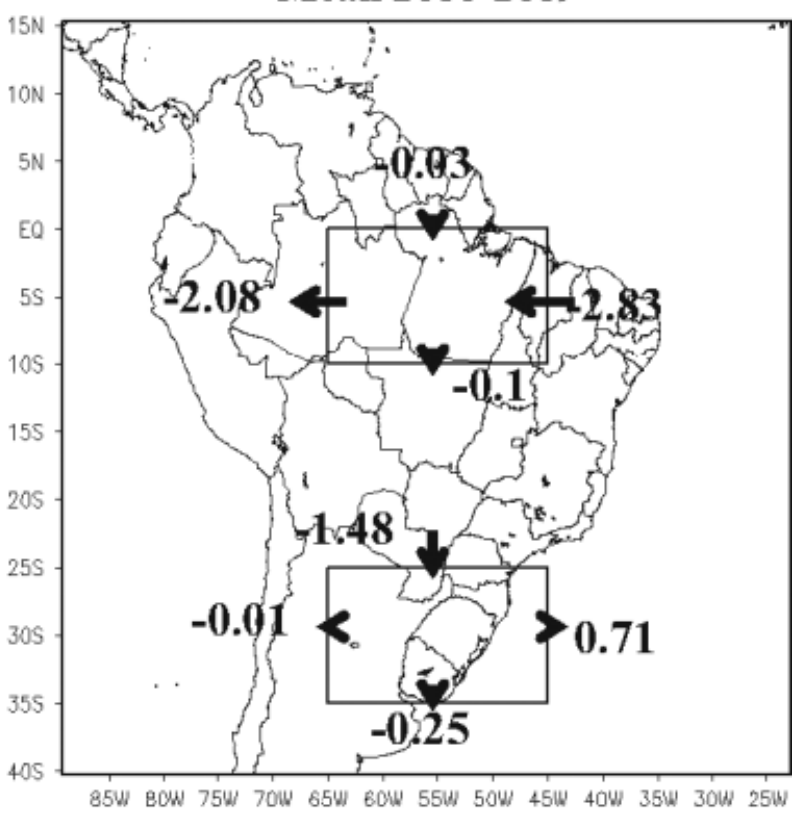

(d)

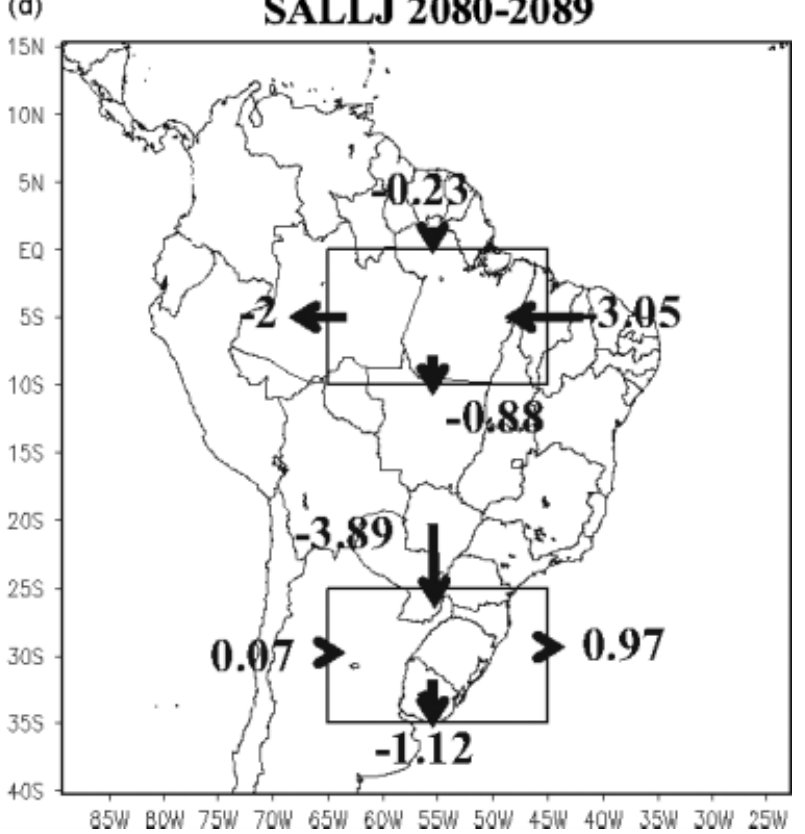

Figure 12. Same as in Figure 10 but for JJA.

increases by about $63 \%$. This increase in all seasons suggests that the SALLJ is more active in the global warming climate scenario than in the current climate, transporting larger amounts of low-level moisture from the Amazon region towards the La Plata Basin. It is also important to highlight that the low-level circulation associated with the SASH also transports moisture to the La Plata region. This moisture flux enters the Amazon box (A) through the WP and NP borders.

In a global warming climate, the trade winds would become more intense due to the higher thermal contrast between the ocean and the continent. Over the Amazon there would be a larger amount of moisture in the lower atmosphere transported from the tropical Atlantic.
This moisture would be channelled by the Andes and transported towards the La Plata Basin more efficiently by the presence of more frequent SALLJ events.

3.5. Impact of the warming scenario and presence of the SALLJ on the moisture convergence and precipitation in the Amazon and La Plata basins

In this section we perform an analysis of the effect of the presence of the SALLJ on the low-level moisture convergence and precipitation over the Amazon and La Plata basins. The convergence and precipitation values are obtained from area average in the boxes $\mathrm{A}$ and $\mathrm{P}$ shown in Figure 1. 

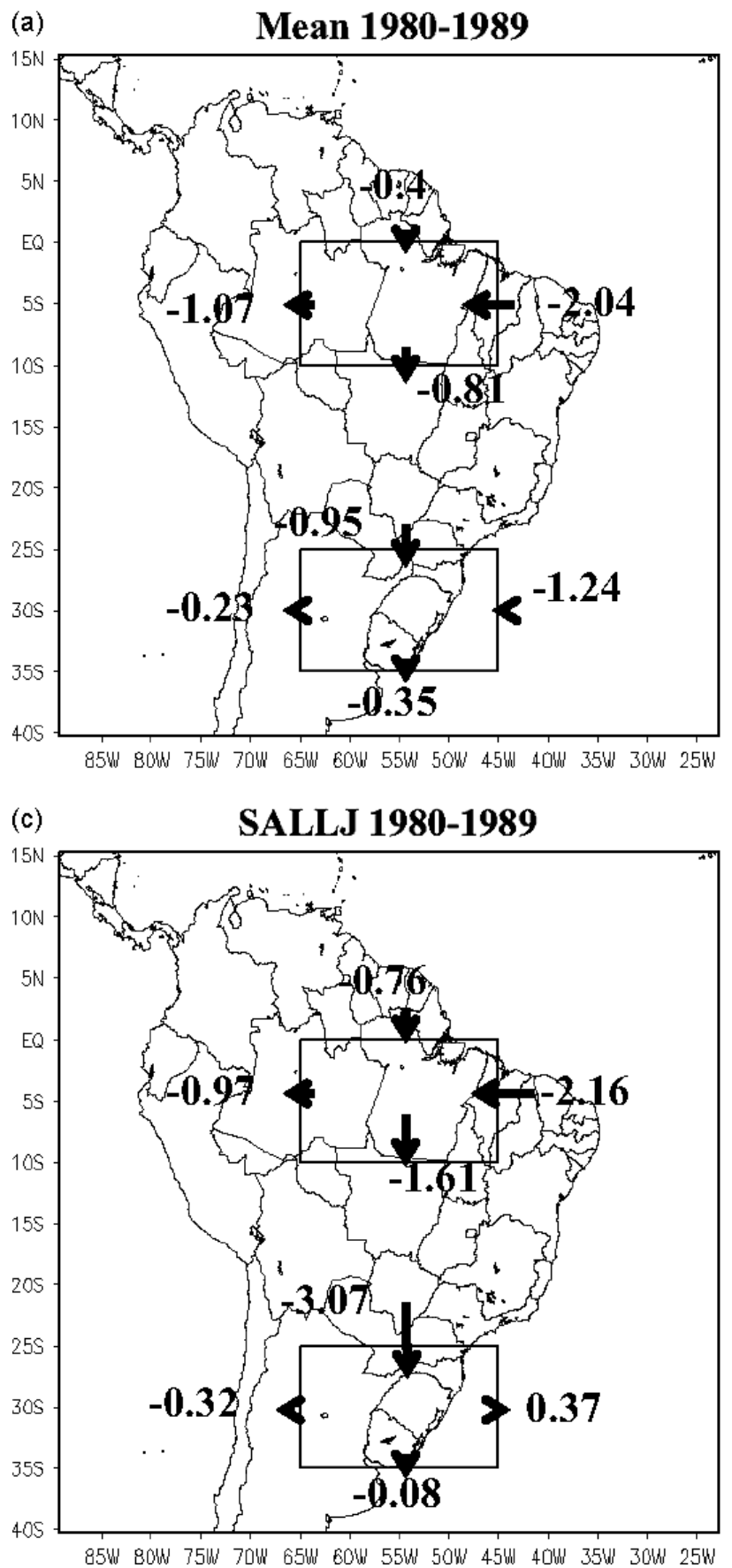

(b)

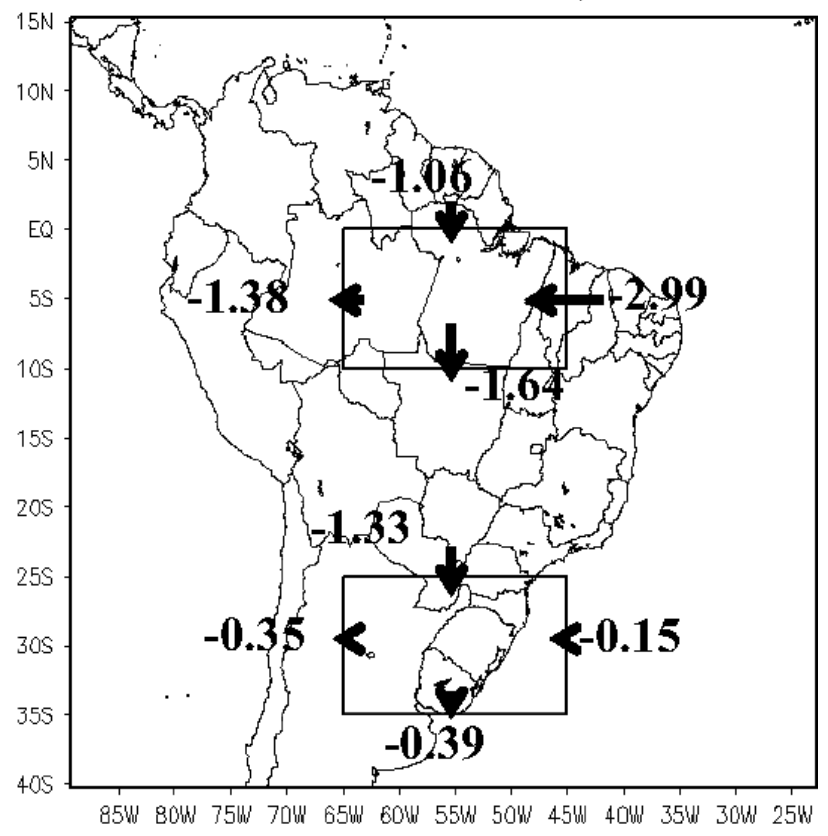

(d)

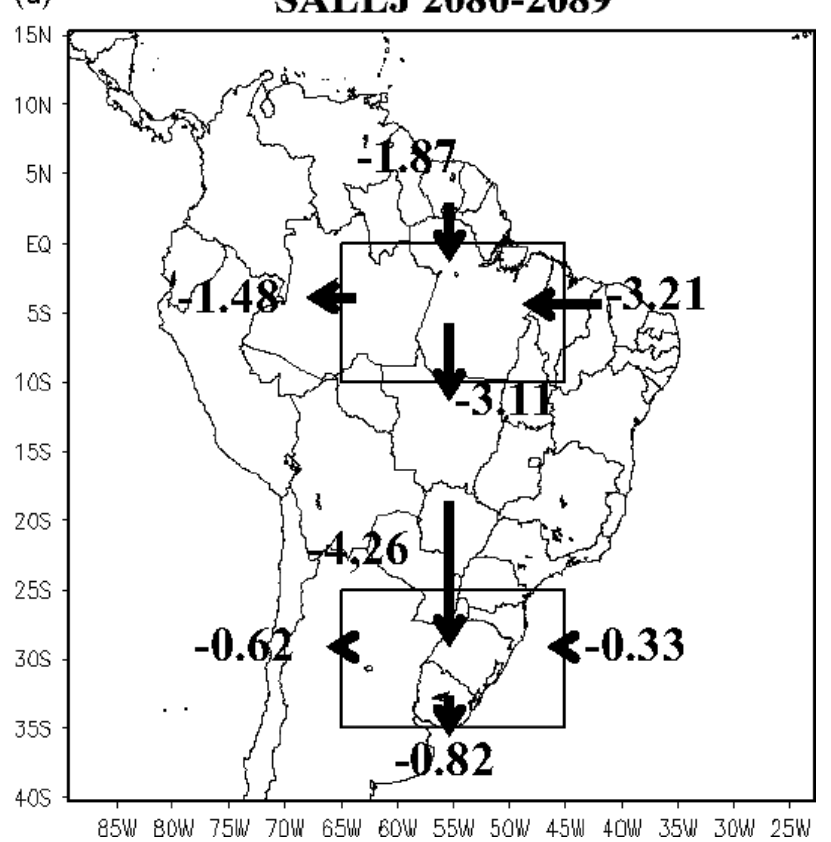

Figure 13. Same as in Figure 10 but for SON.

In the Amazon Basin the HadRM3P underestimates the convergence as compared to values obtained from the NCEP-NCAR data, while in the La Plata Basin an overestimation of the convergence of the regional model in relation to that of NCEP-NCAR is seen.

Figure 14, which compares the values of mean convergence in the present to that of the future climate simulated by HadRM3P, shows during DJF, MAM, JJA and SON that an increase can also be observed in the moisture convergence in the Amazon in the global warming scenario. This increase in the average moisture convergence in area A occurs mainly through the strengthening of the moisture flow associated with the trade winds (not shown) as a response to the higher differential warming (continent/ocean). In winter, the $\mathrm{SASH}$ is more active and closer to the continent, which also strengthens the trades and provides them with a more zonal exit, as shown by Marengo et al. (2004).

Figure 14 shows that the presence of the SALLJ in the current climate as well as in the SRES A2 global warming scenario induces a reduction of convergence in the Amazon region. Figure 10 shows that the moisture flux that comes out of the Amazon region through the WA and SP borders is quite strong in the presence of the SALLJ composite in the present climate as well as in the global warming scenario. 


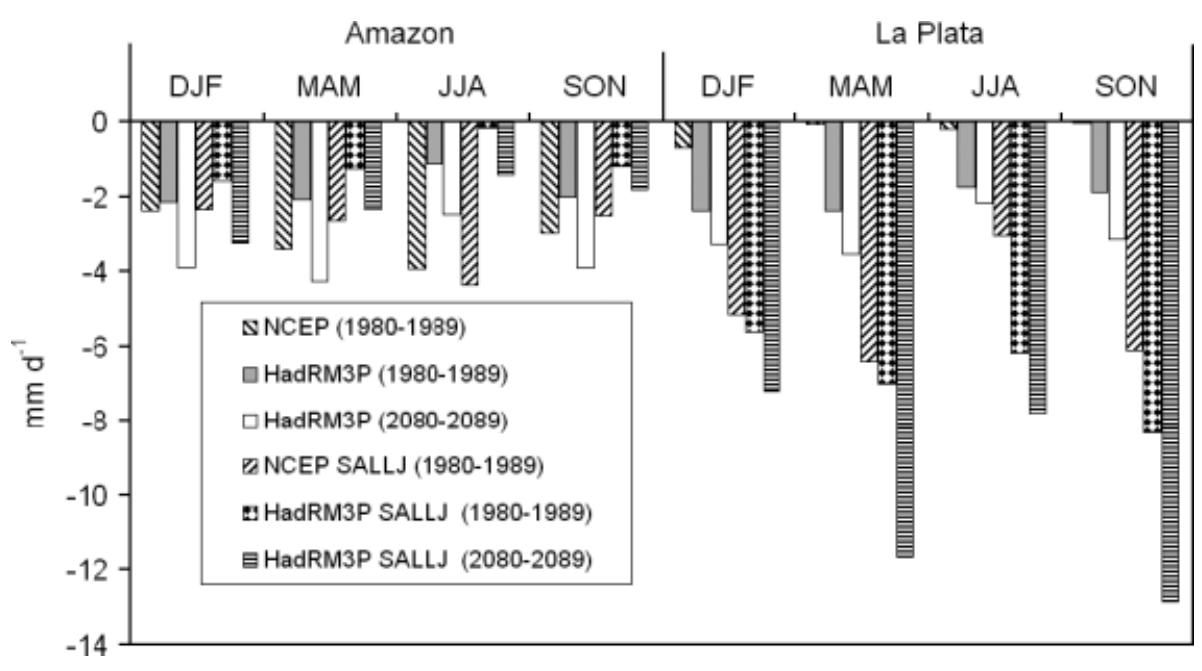

Figure 14. Moisture divergence in the Amazon and La Plata basins. Negative values of divergence indicate convergence. Units are $\mathrm{mm} \mathrm{d}^{-1}$.

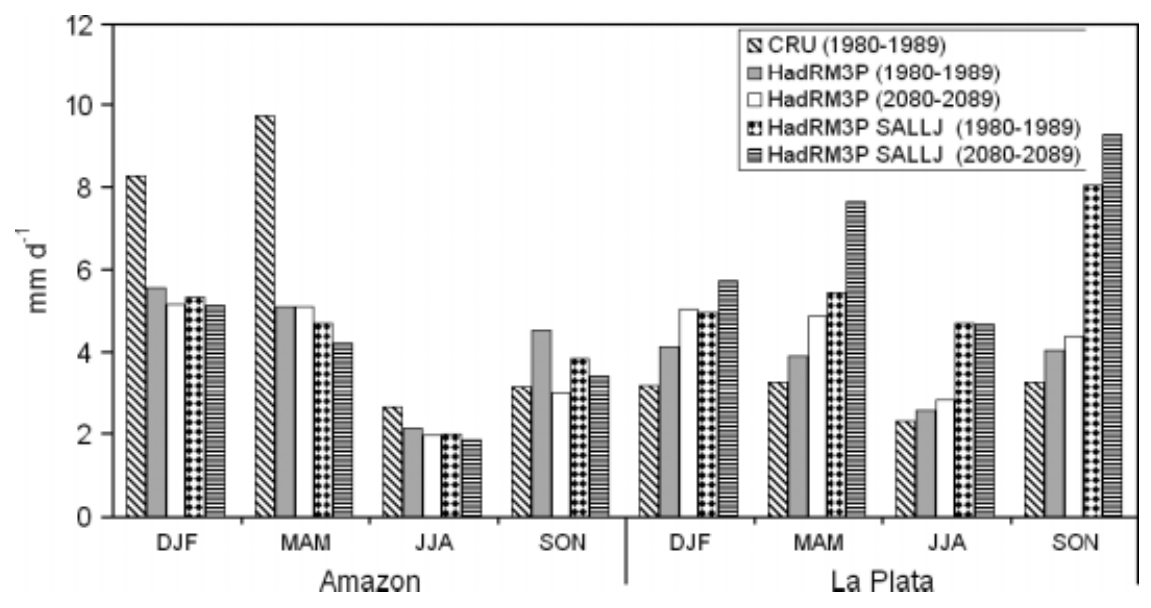

Figure 15. Precipitation in the Amazon and La Plata basins. Units are $\mathrm{mm} \mathrm{d}^{-1}$.

Comparing the effect on the SALLJ for the present versus the future climate, it is shown that in the Amazon region, there is an increase of the convergence in the SRES A2 scenario. This is due to the fact that the moisture flux that enters the Amazon is intensified in the SRES A2. This intensification can be observed on the border EA when comparing Figures 10(d) to (c), 11(d) to (c), 12(d) to (c) and 13(d) to (c) at a seasonal level.

For the La Plata Basin, the right side of Figure 14 shows that in the mean there is an increase of the moisture convergence in SRES A2 as compared to the average value for the present climate. This is because the flux that leaves the Amazon mainly through the SA and WA borders and that reaches the La Plata Basin is more intense in the global warming scenario.

In the La Plata Basin the effect of the presence of the SALLJ along the east side of the Andes, in the current climate as well as in the global warming climate, is opposite to that in the Amazon Basin. This means that in the La Plata Basin the moisture convergence increases in the presence of the jet precisely because the flows that penetrate this basin are intensified, as discussed in the previous session. The comparison of the SALLJ composite in the global warming scenario versus the present climate, at the seasonal level, suggests that there is a higher moisture convergence in the La Plata Basin in SRES A2. This happens because the flow that enters the NP border is stronger.

The analyses have shown that due to the fact that the moisture flux becomes more intense in the global warming scenario, a larger horizontal moisture convergence over the Amazon and La Plata basins may occur. Furthermore, the presence of the SALLJ in both present and future climates suggests an increase in the moisture flux that crosses the western and southern boundaries of the Amazon, generating a decrease in the moisture convergence over the Amazon and an increase over the La Plata Basin.

This apparent acceleration of the hydrological cycle can also explain the increases in the frequency of the extreme rainfall events in the southern part of Brazil-Uruguay-northern Argentina region, as detected by Marengo et al. (2007) for the IPCC SRES A2 scenario.

With regard to precipitation, Figure 15 shows that for the present climate, the HadRM3P simulates less rainfall in Amazonia in the SALLJ composite, with an annual 
cycle characterized by large values in summer and lower in winter. For the global warming scenario, the tendency for less rainfall in the SALLJ composite, observed in the present, still remains. The annual cycle is similar to that of the present, with the exception of SON. In the La Plata, the presence of the SALLJ increases precipitation in both present and future, but for the future, these increases are accentuated. Generally, under strong global warming, the model simulations indicate that Amazonia will have a drier climate with less rain throughout the year, but that the La Plata Basin will have a larger quantity of rain, possibly in the form of intense rainfall events. These results support those of Marengo et al. (2008), which showed that more extreme rain events in the southern region of Brazil are simulated under the SRES A2 scenario.

Figure 15 shows that in the current climate as well as in the warming scenario when the SALLJ is present, the Amazon region has less rain. The contrary occurs in the La Plata Basin, where a larger quantity of rain is observed when the SALLJ events are occurring.

Larger quantities of rain are observed in the presence of the SALLJ in the warming scenario. This can be attributed to the more intense flux of moisture associated with the jet, causing more moisture convergence in this region, as can be seen in Figure 14. This may be in the form of extreme rainfall events.

\section{Conclusions}

Simulations of warmer future climates projected by the HadRM3P regional model from the UK Hadley Centre suggest that in the IPCC SRES A2 scenario, to the east of the Andes the projections show a higher frequency of SALLJ events, as compared to the present. Besides this higher frequency, the regional model projections also suggest an increase in the speed of the SALLJ in the global warming scenario.

The SALLJ composites for the present climate show an increase of meridional moisture transport in the lower atmosphere, mainly in an area along the eastern side of the Andes, towards southeastern South America, as many papers have suggested (Saulo et al., 2000; Nicolini et al., 2002; Marengo et al., 2004; Saulo et al., 2007 and Salio et al., 2007). In the global warming scenario, the presence of the SALLJ intensifies significantly the meridional moisture transport in this region due to an increase in the meridional temperature gradient between tropical and subtropical South America east of the Andes.

The largest moisture transport that happens in the presence of the SALLJ in a global warming scenario climate is due to a higher wind speed and moisture content in the lower level of the atmosphere, although there are differences in the intensity of the annual cycle of the wind, and a higher wind speed in the lower levels of the atmosphere has been detected in the global warming scenario throughout the year.

The comparison of the SALLJ composites for the present and future has shown an increase in the moisture flow across all the lateral boundaries of the Amazon and La Plata basins. Thus, in a global warming scenario, mainly in the La Plata Basin, due to the maximum moisture convergence, this could imply higher moisture amounts available to feed the convective mesoscale systems, which form in this region, and possibly increase the frequency of the rainfall extremes.

On the other hand, the results presented here have shown that the presence of the jet has caused a decrease of the moisture convergence in the Amazon in the current climate as well as in the global warming climate, suggesting less rainfall during SALLJ events, mainly in central and eastern Amazonia. In the present climate, less intense moisture fluxes were detected in the subtropical Atlantic Ocean in the presence of the SALLJ.

The average flow east of the Andes in SRES A2 is higher than in the period from 1980 to 1989 and becomes even higher in the presence of the SALLJ. This suggests that the SALLJ transports moisture more efficiently in the global warming scenario SRES A2 and this could imply an increase of the precipitation in this region, especially in the form of frequent extreme rain events.

The integration of the moisture flux along the lateral boundaries of the Amazon and La Plata boxes has shown that in the global warming climate in the Amazon region, the average moisture flux is more intense. Therefore, the presence of the SALLJ in both the present climate and the future SRES A2 warm climate has caused an increase of the moisture flux that crosses the west and/or south boundaries of the Amazon, causing a decrease of the horizontal moisture convergence there and an increase in the region of the La Plata Basin. A higher moisture concentration may be available to be transported by the SALLJ down to the southeastern region of South America. Thus, the SALLJ can work as a modulator of the hydrological cycle between the two regions and lead to an even higher convection and possibly more extreme events of rain in the south/southeast region of South America in a global warming scenario. Therefore, the annual cycle has shown a higher amount of moisture from the tropical Atlantic transported by the intensified trade winds, due to a warmer climate, and this allows for a higher amount of moisture in the lower atmosphere that is transported by the SALLJ.

We want to emphasize that the simulations presented in this article do not consider changes in the vegetation, such as the deforestation of the Amazon and also the 'Amazon die-back' effect (Cox et al., 2000) which could, in a global warming scenario caused by higher concentration of greenhouse gases, have opposite impacts on the hydrological cycle over South America. Correia et al. (2007); Sampaio et al. (2007) and Salazar et al. (2007) showed in their studies of the deforestation effects in the Amazon that the region is becoming drier. Thus, in a scenario of strong warming like SRES A2, a higher moisture transport from the north associated with the SALLJ is detected. Deforestation would lead to a weakening of such transport since there would be a smaller amount of 
moisture in the lower atmosphere available to be transported by the SALLJ to the south/southeast region of South America.

Since we used only one model run in this study, we were aware of the limitations in reliability. Uncertainties in these simulations can only be reduced by making painstaking improvements in our knowledge of the climate system and of global climate models such as HadCM3. Other aspects of the simulated changes might be more sensitive to the formulation of the regional model itself.

For stakeholders in each of the regions covered, these modelled changes and uncertainties pose different challenges for the management of water resources. For the scientific community, the challenge raised is how to incorporate this uncertainty in climate change projections in a way that allows those groups to make informed decisions based on model projections.

\section{Aknowledgements}

The authors thank the Foundation of Support for Research of São Paulo State (FAPESP - Reference No. 02/126706), the UK GOF-Dangerous Climate Change project, PROBIO, GEOMA and LBA Instituto do Milenio II projects for their financial support for the development of this article. Also, they thank, especially, the Hadley Centre for Climate Research and Prediction, UK for enabling the use of the PRECIS modelling system and data for the simulations of future climates.

\section{References}

Alves L. 2007. Simulações da variabilidade do clima presente sobre a América do Sul utilizando um modelo climático regional, Master Science Dissertation, INPE. São José dos Campos, Brazil.

Ambrizzi T, Rocha R, Marengo J, Pisnitchenko AI, Alves L, Fernandez JP. 2007. Cenários regionalizados de clima no Brasil para o século XXI: projeções de clima usando três modelos regionais". Relatório 3, Ministério do Meio Ambiente, Secretaria de Biodiversidade e Florestas, Diretoria de Conservação da Biodiversidade - Mudanças climáticas globais e efeitos sobre a biodiversidade - Sub projeto: Caracterização do clima atual e definição das alterações climáticas para o território brasileiro ao longo do século XXI. Brasilia, 108 .

Berbery HE, Collini E. 2000. Springtime precipitation and water vapor flux over southeastern South American. Monthly Weather Review 128: $1328-1346$.

Berri GJ, Inzunza B. 1993. The effect of the low-level jet on the poleward water vapor transport in the central region of South America. Atmospheric Environment 27A: 335-341.

Bonner WD. 1968. Climatology of the Low-Level Jet. Monthly Weather Review 96: 833-850.

Bonner WD, Paegle J. 1970. Diurnal variations in boundary layer winds over the south-central United States in summer. Monthly Weather Review 98: 735-744.

Chou SC, Bustamante JF, Gomes JL. 2005. Evaluation of Eta model seasonal precipitation forecasts over South America. Nonlinear Processes in Geophysics 12: 537-555.

Christensen JH, Hewitson B, Busuioc A, Chen A, Gao X, Held I, Jones R, Kolli RK, Kwon WT, Laprise R, Magaña Rueda V, Mearns L, Menéndez CG, Räisänen J, Rinke A, Sarr A, Whetton P. 2007. Regional climate projections. In Climate Change 2007: The Physical Science Basis, Contribution of Working Group I to the Fourth Assessment Report of the Intergovernmental Panel on Climate Change, Solomon S, Qin D, Manning M, Chen Z, Marquis M, Averyt KB, Tignor M, Miller HL (eds). Cambridge University Press: Cambridge, New York, Chapter 11.
Correia FWS, Manzi OA, Candido AL. 2007. Balanço de umidade na Amazônia e sua sensibilidade às mudanças na cobertura vegetal. Ciencia e Cultura 59: 39-43, ISSN 0009-6725.

Cox PM, Betts RA, Jones CD, Spall SA, Totterdell IJ. 2000. Acceleration of global warming due to carbon-cycle feedbacks in a coupled climate model. Nature 408: 184-187.

Douglas MW, Nicolini M, Saulo C. 1998. Observational evidences of a Low-Level Jet east of the Andes during January-March 1998. Meteorologica 3: 63-72.

Giorgi F, Mearns LO. 1999. Introduction to special section: Regional climate modeling revisited. Journal of Geophysical Research 104(D6): 6335-6352.

Gordon C, Cooper C, Senior CA, Banks H, Gregory JM, Johns TC, Mitchell JFB, Wood RA. 2000. The simulation of SST, sea ice extent and ocean heat transports in a version of the Hadley Centre coupled model without flux adjustments. Climate Dynamics 16: 147-168.

Herdies LD, Da Silva A, Dias MAF. 2002. Moisture budget of the bimodal patter of summer circulation over South America. Journal of Geophysical Research 107(D20): 8075, DOI 10.1029/2001JD000997.

Intergovernmental Panel on Climate Change IPCC. 2007a. Climate Change 2007: The Physical Science Basis Summary for Policymakers Contribution of Working Group I to the Fourth Assessment Report of the Intergovernmental Panel on Climate Change, 18.

Intergovernmental Panel on Climate Change IPCC. 2007b. Working Group II Contribution to the Intergovernmental Panel on Climate Change Fourth Assessment Report Climate Change 2007: Climate Change Impacts, Adaptation and Vulnerability, Summary for Policymakers, 23.

Jones RG, Murphy JM, Hassell DC, Woodage MJ. 2005. A high resolution atmospheric GCM for the generation of regional climate scenarios. Hadley Centre Technical Note 63, Met Office, Exeter.

Jones RG, Noguer M, Hassel DC, Hudson D, Wilson SS, Jenkins GJ, Mitchell JFB. 2004. Generating High Resolution Climate Change Scenarios Using PRECIS. Meteorological Office Hadley Centre: Exeter; 40.

Kalnay E, Kanamitsu M, Kistler R, Collins W, Deaven D, Gandin L, Iredell M, Saha S, White G, Woollen J, Zhu Y, Leetmaa A, Reynolds B. 1996. The NCEP/NCAR reanalysis project. Bulletin of the American Meteorological Society 77: 437-471.

Li W, Fu R, Dickinson E. 2006. Rainfall and its seasonality over the Amazon in the 21 st century as assessed by the coupled models for the IPCC AR4. Journal of Geophysical Research 111: D02111.

Liebmann B, Kilads GN, Vera CS, Saulo C, Carvalho LMV. 2004. Subseasonal variations of rainfall in South America in the vicinity of the low-level jet east of the Andes and comparison to those in the South Atlantic convergence zone. Journal of Climate 17: 3829-3842.

Marengo JA. 2005. Characteristics and variability of the water budget in the Amazon Basin. Climate Dynamics 24: 11-22.

Marengo JA, Ambrizzi T. 2006. Use of regional climate models in impacts assessments and adaptations studies from continental to regional and local scales, Procedings of 8 ICSHMO, INPE, 291-296.

Marengo JA, Jones R, Alves L, Valverde MC. 2008. Future change of temperature and precipitation extremes in South America as derived from the PRECIS regional climate modeling system. International Journal of Climatology (Submitted).

Marengo JA, Soares WR. 2002. Episódios de jatos em baixos níveis ao leste dos Andes durante 13-19 de abril de 1999. Revista Brasileira de Meteorologia 17: 35-52.

Marengo JA, Soares WR, Nicolini M, Saulo C. 2004. Climatology of Low-Level Jet East of the Andes as derived from the NCEPNCAR reanalysis: Characteristics and temporal variability. Journal of Climate 17: 2261-2280.

Meehl GA, Stocker TF, Collins WD, Friedlingstein P, Gaye AT, Gregory JM, Kitoh A, Knutti R, Murphy JM, Noda A, Raper SCB, Watterson IG, Weaver AJ, Zhao Z-C. 2007. Global Climate Projections. In Climate Change 2007: The Physical Science Basis, Contribution of Working Group I to the Fourth Assessment Report of the Intergovernmental Panel on Climate Change, Solomon S, Qin D, Manning M, Chen Z, Marquis M, Averyt KB, Tignor M, Miller HL (eds). Cambridge University Press: Cambridge, New York, Chapter 10.

Misra V, Dirmeyer P, Kirtman B, Huang H, Kanamitsu M. 2000. Regional simulation of Interannual Variability over South América. COLA Technical Report, USA, 85.

Nakicenovic N, Alcamo J, Davis G, de Vries B, Fenhann J, Gaffin S, Gregory K, Grubler A, Jung TY, Kram T, La Rovere EL, 
Michaelis L, Mori S, Morita T, Pepper W, Pitcher H, Price L, Riahi K, Roehrl A, Rogner H-H, Sankovski A, Schlesinger M, Shukla P, Smith S, Swart R, van Rooijen S, Victor N, Dadi Z. 2000. Special report on emissions scenarios Cambridge, 599.

New M, Todd M, Hulme M, Jones P. 2001. Precipitation measurements and trends in the twentieth century. International Journal of Climatology 21: 1899-1922.

Nicolini MP, Salio JJ, Katzfey J, McGregor L, Saulo AC. 2002. January and July regional climate simulation over South American. Journal of Geophysical Research 107(D22): 4637.

Nicolini M, Saulo C. 2006. Modeled Chaco low-level jets and related precipitation patterns during the 1997-1998 warm season. Meteorology and Atmospheric Physics 94: 129-143, DOI 10.1007/s00703-006-0186-7.

Nogués-Paegle JN, MO KC. 1997. Alternating wet and dry conditions over south america during summer. Monthly Weather Review 125: 279-291.

Paegle JA. 1998. A comparative review of South American low-level jets. Meteorologica 3: 73-82.

Pope VD, Gallani ML, Rowntree PR, Stratton RA. 2000. The impact of new physical parametrizations in the Hadley Centre climate model - HadAM3. Climate Dynamics 16: 123-146.

Rao VB, Chapa SR, Franchito SH. 1999. Decadal variation of atmosphere-ocean interaction in the tropical Atlantic and its relationship to the Northeast-Brazil rainfall. Journal of the Meteorological Society of Japan 77: 63-75.

Rayner NA, Parker DE, Horton EB, Folland CK, Alexander LV, Rowell DP, Kent EC, Kaplan A. 2003. Global analyses of sea surface temperature, sea ice and night marine air temperature since the late nineteenth century. Journal of Geophysical Research 108(D14): 4407, DOI 10.1029/2002JD002670.

Robock A, Scholosser CA, Vinnikov KY, Speranskaya NA, Entin JK, Qui S. 1998. Evaluation of the AMIP soil moisture simulations. Global and Planetary Change 19: 181-202.

Rowell DP. 2005. A scenario of European climate change for the late twenty-first century: Seasonal means and interannual variability. Climate Dynamics 25: 837-849, DOI:10.1007/s00382-005-0068-6.

Salati E. 1987. The forest and the hydrological cycle. In Amazonian Deforestation and Climate, Gash JH, Nobre CA, Roberts JM, Victoria RL (eds). John Wiley and Sons: Chichester; 273-296.

Salazar L, Nobre C, Oyama M. 2007. Climate change consequences on the biome distribution in tropical South America. Geophysical Research Letters 34: L09708, DOI:10.1029/2007GL029695.

Salio P, Nicolini M, Saulo C. 2002. Chaco low-level jet events characterization during the austral summer season. Journal of Geophysical Research 107(D24): 4816, 10.1029/2001JD001315. 34.
Salio P, Nicolini M, Zipser EJ. 2007. Mesoscale convective systems over Southeastern South America and their relationship with the South American low-level jet. Monthly Weather Review 135: 1290-1309, DOI: 10.1175/MWR3305.1.

Sampaio G, Nobre C, Costa HM, Satyamurty P, Soares-Filho BS, Cardoso M. 2007. Regional climate change over eastern Amazonia caused by pasture and soybean cropland expansion. Geophysical Research Letters 34: L17709, DOI:10.1029/2007GL030612.

Saulo C, Nicolini M, Chou SC. 2000. Model characterization of the South American low-level flow during the 1997-98 spring-summer season. Climate Dynamics 16: 867-881.

Saulo C, Ruiz J, Skabar YG. 2007. Synergism between the low-level jet and organized convection at its exit region. Monthly Weather Review 135: 1310-1326, DOI: 10.1175/MWR3317.1.

Seluchi ME, Saulo AC, Nicolini M, Satyamurty P. 2003. The Northwestern Argentinean low: A study of two typical events. Monthly Weather Review 131: 2361-2378, DOI: 10.1175/15200493(2003)131.

Solman SA, Cabré MF, Nuñez MN. 2008. Regional Climate Change experiments over southern South America. I: Present climate Climate Dynamics 30: 533-552, DOI:10.1007/s00382-007-0304-3.

Uccellini LW, Johnson DR. 1979. The coupling of upper and lower tropospheric jet streaks and implications for the development of severe convective storms. Monthy Weather Review 107: 682-703.

Vera C, Baez J, Douglas M, Emmanuel CB, Marengo JA, Meitin J, Nicolini M, Nogues-Paegle J, Paegle J, Penalba O, Salio P, Saulo C, Silva Dias MA, Silva Dias P, Zipser E. 2006a. The South American low-level jet experiment. Bulletin of the American Meteorological Society 87: 63-77.

Vera CS, Silvestri G, Liebmann B, González P. 2006b. Climate change scenarios for seasonal precipitation in South America from IPCC-AR4 models. Geophysical Research Letters 33: L13707, DOI:10.1029/2006GL025759.

Vera C, Higgins W, Amador J, Ambrizzi T, Garreaud R, Gochis D, Gutzler D, Lettenmaier D, Marengo JA, Mechoso CR, NoguesPaegle J, Silva Dias P, Zhang C. 2006c. Toward a Unified View of the American monsoon systems 4977-5000. Journal of Climate 19: WN: 0628807462003

Vernekar AD, Kirtman BP, Fennessy MJ. 2003. Low-Level Jets and their effects on the South America summer climate as simulated by the NCEP Eta/CPTEC model. Journal of Climate 16: 297-311.

Whiteman C, Bian X, Zhong S. 1997. Low-level jet climatology from enhanced rawinsonde observations at a site in the southern Great Plains. Journal of Applied Meteorology 36: 1363-1375. 